NBER WORKING PAPER SERIES

\title{
MACROPRUDENTIAL FX REGULATIONS: SHIFTING THE SNOWBANKS OF FX VULNERABILITY?
}

\author{
Toni Ahnert \\ Kristin Forbes \\ Christian Friedrich \\ Dennis Reinhardt \\ Working Paper 25083 \\ http://www.nber.org/papers/w25083 \\ NATIONAL BUREAU OF ECONOMIC RESEARCH \\ 1050 Massachusetts Avenue \\ Cambridge, MA 02138 \\ September 2018
}

The views in this paper are those of the authors and do not necessarily represent the views of any institution with which they are affiliated. We would like to thank Jason Allen, Ricardo Correa, Jeffrey Frankel, Glenn Hoggarth, Patrick Honohan, Matias Ossandon Busch, Ian Marsh, Brad Setser, Frank Smets, Livio Stracca, and participants at the AEA 2018 meetings in Philadelphia, the Global Linkages conference in Dublin, the NBER conference on Capital Flows, Currency Wars and Monetary Policy in Cambridge, the Emerging Markets Group Workshop on International Capital Flows: Drivers and Policy Responses in London, the annual conference of the Canadian Economics Association in Montreal, and the IBEFA summer meeting in Vancouver for valuable comments. Further thanks to Matthew Cormier, Min Jae Kim, Duncan Whyte, and Sanjana Bhatnagar for outstanding research assistance and to Jérôme Vandenbussche, Ursula Vogel and Enrica Detragiache for sharing their data. The views expressed herein are those of the authors and do not necessarily reflect the views of the National Bureau of Economic Research.

NBER working papers are circulated for discussion and comment purposes. They have not been peer-reviewed or been subject to the review by the NBER Board of Directors that accompanies official NBER publications.

(C) 2018 by Toni Ahnert, Kristin Forbes, Christian Friedrich, and Dennis Reinhardt. All rights reserved. Short sections of text, not to exceed two paragraphs, may be quoted without explicit permission provided that full credit, including $\odot$ notice, is given to the source. 
Macroprudential FX Regulations: Shifting the Snowbanks of FX Vulnerability?

Toni Ahnert, Kristin Forbes, Christian Friedrich, and Dennis Reinhardt

NBER Working Paper No. 25083

September 2018

JEL No. F32,F34,G15,G21,G28

\section{ABSTRACT}

Can macroprudential foreign exchange $(\mathrm{FX})$ regulations on banks reduce the financial and macroeconomic vulnerabilities created by borrowing in foreign currency? To evaluate the effectiveness and unintended consequences of macroprudential FX regulations, we develop a parsimonious model of bank and market lending in domestic and foreign currency and derive four predictions. We confirm these predictions using a rich dataset of macroprudential FX regulations. These empirical tests show that FX regulations:(1) are effective in terms of reducing borrowing in foreign currency by banks; (2) have the unintended consequence of simultaneously causing firms to increase FX debt issuance; (3) reduce the sensitivity of banks to exchange rate movements, but (4) are less effective at reducing the sensitivity of corporates and the broader financial market to exchange rate movements. As a result, FX regulations on banks appear to be successful in mitigating the vulnerability of banks to exchange rate movements and the global financial cycle, but partially shift the snowbank of FX vulnerability to other sectors.

Toni Ahnert

Financial Studies Division

Bank of Canada

234 Wellington $\mathrm{St}$

Ottawa, Ontario, K1A 0G9

CANADA

tahnert@bankofcanada.ca

Kristin Forbes

MIT Sloan School of Management

100 Main Street, E62-416

Cambridge, MA 02142

and CEPR

and also NBER

kjforbes@mit.edu
Christian Friedrich

Bank of Canada

234 Laurier Avenue West

Ottawa, Ontario, K1AOG9

Canada

cfriedrich@bankofcanada.ca

Dennis Reinhardt

Bank of England,

Threadneedle Street

London EC2R 8AH

dennis.reinhardt@bankofengland.co.uk 


\section{Introduction}

The global financial crisis has prompted renewed interest in tools to reduce macroeconomic and financial vulnerabilities, strengthen financial systems, and improve country resilience. A key component of this strategy is greater use of macroprudential tools such as countercyclical capital buffers, tighter reserve ratios, leverage ratios, and restrictions on loan-to-value and debt-to-income ratios. Several papers have analyzed the use and effectiveness of many of these tools. ${ }^{1}$ One type of tool, macroprudential foreign exchange (FX) regulations, however, has received less attention, despite the long-standing research documenting the vulnerabilities associated with currency mismatch.

This paper seeks to fill this gap. It provides a detailed assessment of macroprudential regulations on the use of foreign currencies by banks, including theoretical predictions of how they could work and then empirical assessments of their direct and unintended consequences using a rich new dataset. We find that macroprudential FX policies are effective in accomplishing their primary goal of reducing bank exposure to foreign currency risk. But do they simply shift the risk elsewhere-similar to "shifting a snowbank" (a pile of snow) from one place to another? We find some evidence of a "shifting snowbank" effect, as reduced FX lending from banks causes some firms to increase FX debt issuance to investors. This shifting is only partial, however, so that aggregate exposure to FX debt declines. Our results also show that these FX regulations reduce the sensitivity of banks to currency movements, but are less successful at reducing the sensitivity of the corporate sector and the broader economy. As a result, although macroprudential FX regulations can substantially improve the resilience of the banking sector to the global financial cycle, the benefits to the broader economy may be more moderate, as some vulnerability shifts to other sectors that may be less informed and make less efficient lending choices.

Exposure to foreign currency borrowing and currency mismatch has been a habitual concern, especially in emerging markets. Foreign currency exposure can increase a country's vulnerability to sudden stops, currency depreciations, and financial and banking crises, as well as limit the ability of the exchange rate and monetary policy to respond to shocks (Rey, 2013). Despite these concerns, foreign currency exposure has continued to increase-especially in the corporate and household sector. ${ }^{2}$ For example, over our sample period from the mid-

${ }^{1}$ Cerutti et al. (2015) and Forbes (2018) are recent surveys of this extensive literature.

${ }^{2}$ See Acharya et al. (2015), Bruno and Shin (2016), Chui et al. (2014, 2016), and Du and Schreger (2016). 
1990s through end-2014, total FX borrowing in international debt securities and bank loans more than tripled to about $\$ 12$ trillion USD. FX borrowing has continued to grow since the 2008 crisis-with cross-border FX borrowing in international debt securities and FX loans increasing by around $\$ 2.5$ trillion USD between 2009 and 2015-a sharp contrast to almost no change in comparable cross-border borrowing in local currency over the same period. Concerns about the macroeconomic and financial risks related to FX exposure have increased interest in using macroprudential FX regulations.

Evaluating the effects of macroprudential FX measures has been challenging, however, partly due to insufficient data linked to the limited experience with these tools until recently, and partly due to identification challenges related to macroprudential regulations being introduced as a response to financial and macroeconomic developments. ${ }^{3}$ An evaluation should assess not only the direct effects of these measures on the intended sector of the economy (such as banks), but also any spillovers or leakages as firms, banks, and other entities respond to the regulations. These types of unintended consequences have been highlighted in analyses of other types of macroprudential regulations and capital controls. ${ }^{4}$ If these leakages and substitution effects occur, can these macroprudential policies achieve their primary goal of reducing aggregate country vulnerability to currency risk?

This paper attempts to tackle these challenges in an assessment of the direct and indirect effects of macroprudential FX regulations on banks and the broader economy. We develop a parsimonious model of bank versus market lending, building on the seminal work of Holmstrom and Tirole (1997), but adding the dimension that lending and borrowing is also differentiated between domestic and foreign currencies. Domestic firms seek funding from lenders, but have private information about their productivity. Banks can screen firms at a cost and identify unproductive, low-productivity, and high-productivity firms, while market investors can only lend indiscriminately. Funding in foreign currency is cheaper than in domestic currency, but subject to exchange rate risk. When the domestic currency depreciates, low-productivity firms and their associated banks default. Macroprudential FX regulation increases banks' cost of funding in foreign currency (if the regulation is a liability-side measure) or the equilibrium lending rate to firms (if an asset-side measure). Banks stop

\footnotetext{
3 Papers which include some discussion of macroprudential FX regulations as part of their broader analyses of macroprudential tools are: Nier et al. (2011), Cerutti et al. (2015), Vandenbussche et al. (2015), and Avdjiev et al. (2016b). Two papers which focus on FX regulations are De Crescenzio et al. (2017) and Aguirre and Repetto (2017), but neither consider the leakages, broader effects on the economy, or sensitivity to currency movements.

4 See Agénor and da Silva (2017) for a recent survey.
} 
lending to low-productivity firms, which respond by shifting some of their foreign currency borrowing from banks to investors. Total factor productivity declines, as FX lending shifts to investors (who cannot screen) and a share of FX lending shifts to less productive firms. The overall impact on welfare is ambiguous and reflects a tradeoff between two forces: FX regulation provides the benefit of reducing the social cost of bank failure after depreciations at the cost of reducing output due to the less efficient allocation of FX lending.

Our simple framework yields four testable implications for how macroprudential FX regulations affect bank and corporate borrowing, cross-border capital flows, FX exposure in different sectors of the economy, and macroeconomic vulnerability to exchange rate movements. After an increase in macroprudential FX regulations: (1) banks borrow and lend less in foreign currency (with no change in their borrowing in local currency); (2) firms shift away from bank borrowing and increase their FX borrowing from market investors (with no increase in firm and bank non-FX borrowing from investors); (3) banks are less exposed to exchange rate movements; and (4) firms experience some reduction in their exposure to exchange rate movements, but less than for banks.

To test these four predictions, we build a rich data set on macroprudential FX regulations, defined as policies directed at the broader financial system (compared to prudential regulations that target individual institutions) and that are based on the currency denomination of the capital transaction. The dataset is based on four sources that each document and measure macroprudential FX regulations in different contexts or for different countries: Shim et al. (2013), Vandenbussche et al. (2015), Cerutti et al. (2017) and Reinhardt and Sowerbutts (2018). Our resulting data set includes information on macroprudential regulations in 48 countries over the period 1995-2014. It has broader country and period coverage of macroprudential FX regulations, as well as a more detailed categorization of different types of regulations, than previously available.

The empirical analysis confirms the four testable implications of the model, as well as provides additional details on how tighter macroprudential FX regulations affect (or do not affect) different types of cross-border capital flows, banks, and sensitivity to currency movements. These results suggest that macroprudential FX regulations on banks are successful in accomplishing their direct goals - of reducing the FX exposure of banks and sensitivity of banks to currency movements. There is also some evidence that this occurs because the regulations reduce domestic lending in FX, increase the average rate at which 
banks lend, and reduce the share of banks' non-performing loans, partly by reducing the number of entities to which they lend. The FX regulations, however, also appear to have the unintended consequence of causing companies to partially shift their FX funding toward international debt issuance, thereby mitigating the reduction in the aggregate exposure of the economy to FX risk. These results are robust to a series of sensitivity tests, including attempts to control for any potential endogeneity in the country's decision to adjust FX measures.

The magnitudes of the estimates also suggest that these direct and indirect effects of macroprudential FX regulations are meaningful. A tightening of FX regulations causes banks to reduce their cross-border borrowing in FX by about a third, a reduction equivalent to about $0.5 \%-0.7 \%$ of GDP. For major emerging markets, such as Brazil or Indonesia, this is equivalent to reducing cross-border bank FX borrowing by more than half. At the same time, corporates increase FX debt issuance by about 10\% of median annual FX debt issuance for the full sample, equivalent to a 15\%-20\% increase in FX corporate debt issuance for emerging markets such as Brazil and Indonesia. Combining these various estimates suggests that FX regulations still cause a meaningful reduction in the aggregate FX borrowing of the countryas the reduction in cross-border FX bank borrowing is substantially greater than the increase in FX corporate debt issuance-but that 10\%-16\% of the aggregate FX exposure shifts from banks to other sectors (such as investors and non-bank financial institutions). The effects are larger if the FX measures focus on bank liabilities instead of bank assets.

Our results have several important implications. They support a growing body of research showing that macroprudential regulations can be effective at accomplishing their direct goals5-in this case significantly reducing the FX exposure of banks to currency movements. This result is particularly relevant for the debate on how to address long-standing concerns about vulnerabilities related to foreign currency borrowing and currency mismatch. ${ }^{6}$ These vulnerabilities have prompted some countries to consider the use of capital controls. Our results suggest that any such countries could instead consider macroprudential FX regulations-especially countries for which capital controls (but not macroprudential FX regulations) are illegal, such as in the European Economic Area and in some trade agreements.

\footnotetext{
5 Prominent examples include: Dell'Ariccia et al. (2011), Ostry et al. (2012), Kuttner and Shim (2013), Akinci and Olmstead-Rumsey (2015), Bruno et al. (2015), Cerutti et al. (2015), Forbes et al. (2015), Vandenbussche et al. (2015), and Beirne and Friedrich (2017).

6 For discussions of "original sin" and vulnerabilities related to foreign currency exposure and mismatch, see Eichengreen and Hausmann (1999), Bordo and Meissner (2005), Desai et al. (2008), Zettelmeyer et al. (2011), Benmelech (2012), and Kearns and Patel (2016).
} 
The analysis also supports a rapidly growing literature that shows that even when macroprudential FX regulations work in terms of their direct goals, there can be leakages and unintended consequences. ${ }^{7}$ Ranciere et al. (2010) highlight the importance of incorporating these potential leakages in any analysis of the impact of macroprudential FX regulations. In our analysis, these leakages are smaller than the direct effects of FX regulations, but still significant and economically meaningful.

Finally, this paper moves beyond most other work on macroprudential regulations by assessing if the regulations achieve the broader goal of improving financial resilience. The results suggest that macroprudential FX regulations can improve the resilience of the banking sector to currency fluctuations, but do less to improve the resilience of the broader economy to currency fluctuations. This may still provide net benefits by improving the resilience of banking institutions that can create broader systemic vulnerabilities, just as when the snowplow moves the snow off the road, it makes the road system safer. Yet, just as the snow plow inevitably pushes a portion of the snow to block your driveway, macroprudential FX regulations can also shift some vulnerability to other sectors that are outside the regulatory perimeter. These other institutions may be harder to monitor and less well informed than banks, less able to screen for the risks inherent in corporate borrowing in FX, and less able to handle subsequent losses after a depreciation. This shifting snowbank of risks could mitigate some of the benefits of the macroprudential FX regulations.

This paper proceeds as follows. Section II presents the theoretical model of bank and market lending in domestic and foreign currency. Section III describes the data, including the compilation of the dataset on macroprudential FX regulations. Section IV presents the empirical framework and reports results on the direct and indirect effects of FX regulations on bank and firm borrowing and debt issuance, including tests assessing the impact of different measures and sensitivity tests. Section V assesses the impact of the regulations on bank and corporate vulnerability to currency movements, including how this corresponds to other measures of bank performance. Section VI concludes.

7 Several papers documenting these leakages of regulations to other sectors are: Aiyar et al. (2014), Reinhardt and Sowerbutts (2015), Cerutti et al. (2015) and Agénor and da Silva (2017). Papers documenting the international spillovers when regulations or capital controls in one country deflect capital flows to others are: Ghosh et al. (2014), Giordani et al. (2014), Pasricha et al. (2015), Forbes et al. (2016), Beirne and Friedrich (2017), and Kang et al. (2017). 


\section{Theoretical Model}

Before assessing the impact of macroprudential FX regulations, we develop a simple framework of bank versus market lending in domestic or foreign currency. This framework shares with the seminal work of Holmstrom and Tirole (1997) the emphasis on asymmetric information between lenders and borrowers, with banks as special lenders because of their ability to reduce the consequences of asymmetric information at a cost. In Holmstrom and Tirole (1997), banks can monitor firms to reduce their moral hazard problem-a channel that is absent in our model. Instead, we focus on how asymmetric information affects a lender's choice of the currency of their loans, where screening allows banks to identify more productive firms that are more likely to remain solvent after currency depreciations. ${ }^{8}$ While Holmstrom and Tirole (1997) consider an environment with a single good, we consider two goods in order to allow for a choice between foreign and domestic currency. Our model is not intended to explain all of the factors that go into firm borrowing decisions, but instead provide structure and a framework for the key channels evaluated in the empirical analysis in the paper. ${ }^{9}$

To begin, assume that there are two dates, $t=0,1$, and a domestic $D$ and a foreign $F$ good. Let $e_{t}$ be the exogenous exchange rate (the value of $D$ goods in terms of $F$ goods) at date $t$. We focus on FX risk (that is, the volatility of the exchange rate), with no changes to its expected level, which we normalize to one, $E_{0}\left[e_{1}\right]=e_{0} \equiv 1$. Specifically, the exchange rate process is bivariate and can involve either depreciation or appreciation:

$$
e_{1} \in\left\{e_{L}, e_{H}\right\}
$$

where $e_{L}<1<e_{H}$ and the probability of an appreciation is $\operatorname{Pr}\left\{e_{1}=e_{H}\right\} \equiv q \in(0,1)$.

The economy is populated by four groups of risk-neutral agents: domestic firms, banks, investors, and savers. There are many banks, investors, and savers, each of whom take the observable funding and lending rates as given and make zero profits due to competition. ${ }^{10} \mathrm{~A}$ unit continuum of savers is each endowed with $K_{D}$ units of the domestic good and $K_{F}$ units of the foreign good, respectively. The outside option of savers is given by constant-returns-toscale technologies that yield $r_{D}$ and $r_{F}<r_{D}$ at $t=1$, respectively. Thus, banks and investors can fund themselves in domestic and foreign currency at these rates. Banks and investors are

${ }^{8}$ Stiglitz and Weiss (1981) is a seminal paper modelling bank screening in a one-good economy.

9 For example, the model and paper do not attempt to explain structural differences across countries in the reliance on bank funding versus other forms of funding.

${ }^{10}$ Our results can be generalized to a setting in which lenders and firms share the surplus from lending. 
hedged, so they obtain funding in the currency of the loan to firms. ${ }^{11}$

At $t=0$, a unit continuum of firms $j \in[0,1]$ has a domestic investment opportunity normalized to unit size. Since firms do not have their own funds, they seek to borrow from either banks or investors in either domestic or foreign currency. Firms are heterogeneous in the productivity of their opportunities, which yield a safe return $A_{j}$ at $t=1$. Firm productivity is private information, but the distribution is publicly known and can take three values:

$$
A_{j} \in\left\{0, A_{L}, A_{H}\right\}
$$

where $0<A_{L}<A_{H}$. A firm has low productivity with probability $\operatorname{Pr}\left\{A_{j}=A_{L}\right\} \equiv p_{L} \in(0,1)$, and high productivity with probability $\operatorname{Pr}\left\{A_{j}=A_{H}\right\} \equiv p_{H} \in\left(0,1-p_{L}\right)$. There is universal protection by limited liability. If a firm cannot repay a loan at $t=1$, the bank or investor seizes its assets. A bankrupt firm receives zero and, for simplicity, the bank or investor recoups its asset value fully. Our results extend to partial recovery upon firm default.

Relative to investors, banks are special in that they have access to a screening technology. Upon paying a fixed cost, $c>0$, a banker can identify the productivity of firms; that is, a banker who screens observes $A_{j}$. In contrast, the investors do not observe firm productivity and, therefore, may be subject to adverse selection. This difference in screening technology is the only source of heterogeneity across different types of lenders.

\section{A. Lending in Domestic Currency}

To start, suppose that funding in foreign currency is unavailable $\left(K_{F}=0\right)$. Let $R_{D}$ denote the competitive lending rate in domestic currency offered by screening banks. In equilibrium, this rate covers the costs of funding in domestic currency and screening:

$$
R_{D}^{*}=r_{D}+c
$$

Unproductive firms, $A_{j}<R_{D}^{*}$, do not receive funding in domestic currency from banks, while productive firms do. Funding in domestic currency is relatively expensive, so only highproductivity firms may attract funding in domestic currency from screening banks:

${ }^{11}$ Such prudential behavior would arise endogenously if banks or investors had charter value (Keeley, 1990). Evidence also suggests that banks are hedged against direct FX risk (e.g., Brauning and Ivashina, 2017; Borio et al., 2017). 


$$
A_{L}<r_{D}+c<A_{H}
$$

As shown in Illustration 1, firms with $A_{j} \in\left\{0, A_{L}\right\}$ receive no funding and do not invest, while high-productivity firms with $A_{j}=A_{H}$ receive funds, invest, and make a safe profit, $\pi_{D}=$ $A_{H}-R_{D}^{*}>0$, which is the entire surplus from lending and investment. We assume that demand for domestic funding can be met, $K_{D}>p_{H}$. When lending is only in domestic currency, little credit and investment occurs, but both firms and banks never default.

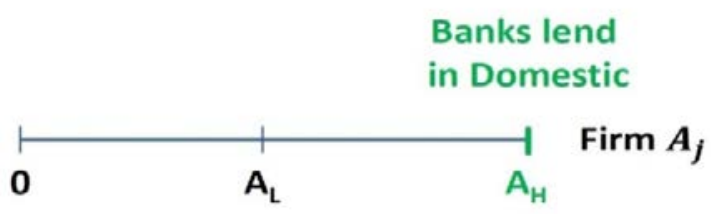

\section{Illustration 1: Banks lend in domestic currency to high-productivity firms.}

To complete the analysis, we study when banks choose to screen. The resulting conditions also ensure that investors choose not to lend to firms in domestic currency (because investors and non-screening banks are identical). Intuitively, the screening cost must be low relative to the consequences of adverse selection faced by investors. ${ }^{12}$

\section{B. Lending in Domestic and Foreign Currency}

We consider $p_{L}<K_{F}<1-p_{H}$, so foreign capital can cover the financing needs of all low-productivity firms, but not that of all zero- and low-productivity firms together. We construct an equilibrium in which banks choose to screen and lend to low-productivity firms in $F$ and to high-productivity firms in $D$. This equilibrium requires (i) low-productivity firms to default after depreciation and (ii) high-productivity firms to prefer stable funding in $D$ over cheaper funding in $F$. Let $R_{F}$ be the competitive lending rate in foreign currency. A bank that screens has opportunity costs $r_{F}+c$; it receives $R_{F}$ after an appreciation and the liquidation

\footnotetext{
12 There are two conditions. First, if $\rho_{D}>r_{D}+c=R_{D}^{*}$, where $\rho_{D}$ is the lending rate of investors, then only firms $A_{j} \in$ $\left\{0, A_{L}\right\}$ may borrow. The investor receives zero from the proportion $\frac{1-p_{L}-p_{H}}{1-p_{H}}$ of unproductive firms and $A_{L}$ from the residual proportion of low-productivity firms (due to partial default, $A_{L}<\rho_{D}$ ). For investors not to choose to lend at this rate, the funding cost in domestic currency must exceed the expected revenue from lending, $r_{D}>\frac{p_{L}}{1-p_{H}} A_{L}$. Second, if $\rho_{D} \leq r_{D}+c$, then high-productivity firms $A_{H}$ may also seek funding from investors. The best possible rate investors can receive is $\rho_{D}=r_{D}+c$. Then, investors do not lend in domestic currency when the funding cost in domestic currency exceeds the expected revenue from lending, $\left(1-p_{L}-p_{H}\right) * 0+p_{L} A_{L}+p_{H} \rho_{D}<r_{D}$, which results in an upper bound on the screening cost, $c<\tilde{c} \equiv \frac{\left(1-p_{H}\right) r_{D}-p_{L} A_{L}}{p_{H}}>0$.
} 
value $A_{L} e_{L}$ after a depreciation (since the domestic firm produces in $D$ goods):

$$
R_{F}^{*}=\frac{r_{F}+c-(1-q) A_{L} e_{L}}{q} .
$$

To verify that firms with productivity $A_{L}$ default after a depreciation, $A_{L} e_{L}<R_{F}^{*}$, we require an upper bound on the exchange rate after depreciation, $e_{L}<\bar{e}_{L} \equiv \frac{r_{F}+c}{A_{L}}$. Conversely, repayment after an appreciation requires $A_{L} e_{H} \geq R_{F}^{*}$. Using $q e_{H}+(1-q) e_{L}=1$, we obtain $A_{L} \geq r_{F}+c$, which results in the intuitive ordering of firm productivity and funding costs:

$$
0<r_{F}+c \leq A_{L}<r_{D}+c<A_{H}
$$

When do high-productivity firms prefer borrowing in domestic over foreign currency? Borrowing in $D$ yields a low but stable profit $\pi_{D}>0$. In contrast, borrowing in $F$ is cheaper. If the tighter upper bound on the exchange rate after depreciation $e_{L}<\widehat{e_{L}} \equiv \frac{r_{F}+c}{A_{H}}$ holds, highproductivity firms default after depreciation, with expected firm profits $\pi_{F}=q\left(A_{H}-\frac{R_{F}}{e_{H}}\right)$. Hence, $\pi_{D}>\pi_{F}$ whenever the benefit of stable funding exceeds the cost differential, (1 q) $\left(A_{H}-A_{L} \frac{e_{L}}{e_{H}}\right) \geq r_{D}+c-\frac{r_{F}+c}{e_{H}}$. Using $E\left[e_{1}\right]=1$, this condition is $A_{H} \geq \underline{A_{H}} \equiv A_{L} \frac{e_{L}}{e_{H}}+$ $\frac{e_{H}-e_{L}}{e_{H}} \frac{e_{H}\left(r_{D}+c\right)-\left(r_{F}+c\right)}{e_{H}-1}$. Intuitively, high-quality firms prefer stable funding in domestic currency over a high loss after a depreciation (associated with foreign currency funding).

Given the competitive lending rate by screening banks, when is it optimal for investors to lend in foreign currency? Let investors offer a rate $\rho_{F}$. If $\rho_{F}>R_{F}^{*}$, only unproductive firms can be attracted, which cannot be optimal. Thus, $\rho_{F} \leq R_{F}^{*}$. Suppose only firms with low productivity are attracted, while high-productivity firms continue to borrow in domestic currency. ${ }^{13}$ The highest possible benefit for investors arises for $\rho_{F}=R_{F}^{*}$, receiving $\frac{p_{L}}{1-p_{H}}\left(q R_{F}^{*}+(1-q) A_{L} e_{L}\right)$. Thus, lending from investors in foreign currency is profitable if the screening cost saving is higher than the cost of adverse selection:

$$
c>\bar{c} \equiv \frac{1-p_{L}-p_{H}}{p_{L}} r_{F}
$$

\footnotetext{
13 When investors also attract high-productivity firms, one can show that lending from investors is profitable in this
} case whenever the screening cost is sufficiently high, $c>\hat{c} \equiv \frac{r_{F}}{e_{H}\left(p_{L}+p_{H}\right)}-r_{D}+(1-q)\left[A_{H}-\frac{e_{L}}{e_{H}} \frac{p_{L} A_{L}+p_{H} A_{H}}{p_{L}+p_{H}}\right]$. 
In sum, the availability of cheap funding in foreign currency increases firm investment as low-productivity firms also receive funds and invest. The downside of this FX-lending induced credit boom is greater exposure to FX risk. After the domestic currency depreciates, low-productivity firms default and banks suffer losses. Illustration 2 shows this equilibrium with both domestic and foreign currency lending (but without macroprudential regulation).

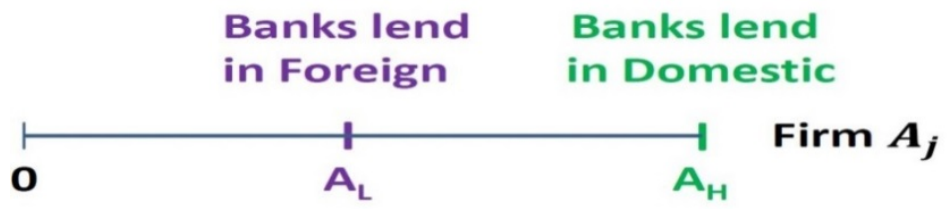

\section{Illustration 2: Equilibrium for $c<\bar{c}$. Banks lend in domestic currency to high- productivity firms and in foreign currency to all low-productivity firms.}

This model therefore implies that high-quality firms receive domestic funding from banks (the preferred option to avoid currency risk), and lower-quality firms receive riskier funding in foreign currency. It is also possible that high quality firms prefer funding in foreign currency, possibly because they export and therefore have a natural hedge against currency risk. We explore this extension below in part $\mathrm{E}$.

\section{Macroprudential FX Regulation of Banks}

Consider a regulator concerned about the financial stability of banks due to a social cost of bank failure $\Delta>0$. When the regulator imposes a macroprudential $\operatorname{tax} \tau>0$ on banks, what is the impact on funding and lending, the sensitivity to FX risk, and welfare?

\section{i. Liability-side measures}

With a macroprudential tax on funding for banks in foreign currency (a liability-side measure), the effective cost of borrowing for banks after the tax is $r_{F}+\tau$. If screening banks were to lend in $F$ to low-productivity firms, the competitive lending rate would be: ${ }^{14}$

$$
R_{F}^{* *}=R_{F}^{*}+\frac{\tau}{q}>R_{F}^{*}
$$

\footnotetext{
14 The conditions for default after depreciation and high-productivity firms preferring borrowing in domestic currency are relaxed. Low-productivity firms are assumed to continue to repay fully after appreciation, $A_{L} \geq r_{F}+c+\tau$.
} 
For intermediate screening costs, banks lend in $F$ without a tax, but stop doing so after the tax, where banks still lend to high-productivity firms in domestic currency:

$$
\frac{1-p_{L}-p_{H}}{p_{L}} r_{F}-\tau \equiv \overline{c_{L}} \leq c<\bar{c}
$$

The benefit of taxing FX borrowing by banks is to reduce FX lending by banks (to zero in our stylized model) and, therefore, reduce the probability of a (socially costly) default of banks after depreciation. In expectation, his benefit amounts to $(1-q) \Delta$. There is a partial substitution from bank lending in $F$ to investor lending in $F$, as low-quality firms now obtain some funding through FX bond issuance. Since investors are not subject to FX regulation, they can still obtain funding in $F$ at the rate $r_{F}$ and lend to firms of productivity $A_{j} \in\left\{0, A_{L}\right\}$.

There is also a cost, however, associated with the tax on FX borrowing by banks. Not all low-productivity firms receive FX funding because of the capacity constraint, $K_{F}<1-p_{H}$, so only a fraction $\frac{K_{F}}{1-p_{H}} \in(0,1)$ of these firms continue to be funded. Also, a fraction $\frac{1-p_{H}-K_{F}}{1-p_{H}}$ of unproductive firms are funded in $F$, so domestic output decreases after macroprudential FX regulation by an amount $p_{L} A_{L} \frac{1-p_{H}-K_{F}}{1-p_{H}}$. Illustration 3 shows the equilibrium.

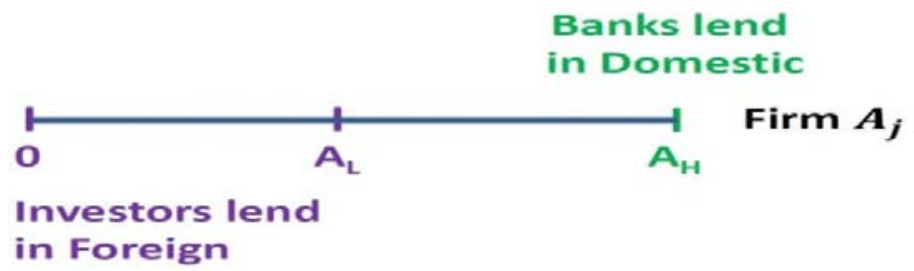

\section{Illustration 3: Equilibrium after macroprudential FX regulation of banks. Banks lend in domestic currency to high-productivity firms and investors lend in foreign currency to some zero- and low-productivity firms (rationing).}

Foreign currency borrowing from investors is feasible as long as adverse selection is not too severe (Akerlof, 1970). Competitive investors are repaid from the fraction $\frac{p_{L}}{1-p_{H}}$ of lowquality firms, receiving $e_{L} A_{L}$ after depreciation, with full repayment $\rho_{F}^{*}$ after appreciation. Thus, the competitive lending rate of investors is:

$$
\rho_{F}^{*}=\frac{\frac{1-p_{H}}{p_{L}} r_{F}-(1-q) e_{L} A_{L}}{q} .
$$


To ensure that investors can still attract low-quality firms, $e_{H} A_{L} \geq \rho_{F}^{*}$, the share of lowproductivity firms must be high enough (in order to limit the extent of adverse selection):

$$
p_{L} A_{L} \geq\left(1-p_{H}\right) r_{F}
$$

\section{ii. Asset-side measures}

Next, we show that if a macroprudential tax is applied to bank lending in foreign currency (an asset-side measure) instead of to bank funding in foreign currency, the result is qualitatively identical. If screening banks were to lend in $F$ to low-productivity firms, the competitive lending rate would be $R_{F}^{* * *}=R_{F}^{*}+\tau>R_{F}^{*}$. Paralleling the previous analysis, we derive an intermediate range of screening costs such that banks lend in $F$ only without a tax:

$$
\frac{1-p_{L}-p_{H}}{p_{L}} r_{F}-q \tau \equiv \overline{c_{A}} \leq c<\bar{c}
$$

where $\overline{c_{L}}<\overline{c_{A}}$. Thus, the range of screening costs for which a given tax reduces bank FX lending and shifts to funding in foreign currency by investors (through debt issuance) is larger for liability- than for asset-side measures. Intuitively, a higher funding cost in foreign currency (from liability-side measures) affects the bank in all states, while a higher lending rate in foreign currency (from asset-side measures) only matters when the firm survives.

\section{iii. Evaluating the impact of macroprudential FX regulation}

Our model shows that macroprudential FX regulations generate both benefits and costs to the broader economy. The primary benefit is avoiding bank failure after depreciations (caused by a default of firms borrowing in FX) - with the attendant social and economic costs documented elsewhere. ${ }^{15}$ The primary cost of FX regulations is a reduction in domestic output due to the credit rationing in foreign funding for low-productivity firms, since investors who cannot screen (mis-)allocate some FX lending to unproductive firms. Taken together, macroprudential FX regulation enhances welfare if and only if:

$$
\Delta \geq \frac{p_{L} A_{L}\left(\frac{1-p_{H}-K_{F}}{1-p_{H}}\right)}{1-q}
$$

15 For estimates of the cost of bank defaults, see Laeven and Valencia (2013). 
FX regulation is more likely to be welfare enhancing if the social cost of bank default is higher, or if the output loss from reduced FX lending to low productivity firms is smaller.

\section{iv. Sensitivity to FX risk}

The sensitivity of banks and firms to FX risk changes after macroprudential regulation. To clarify how it changes, we consider the interim range of information costs derived in the previous two subsections, $\overline{c_{A}}<c<\bar{c}$, such that banks lend to low-productivity firms in $F$ without regulation and investors lend after FX regulation. After FX regulation, the exposure of banks to FX risk is reduced, while the exposure of investors increases.

More specifically, in our model, realized bank profit before FX regulation is sensitive to FX risk and can be expressed as:

$$
\begin{aligned}
& \pi^{B}=\frac{1-q}{q}\left(r_{F}+c-A_{L} e_{L}\right)>0 \text { if } e=e_{H}, \\
& \pi^{B}=A_{L} e_{L}-\left(r_{F}+c\right)<0 \text { if } e=e_{L} .
\end{aligned}
$$

In contrast, after macroprudential FX regulation, no bank lends in $F$ and no bank fails after a depreciation of the domestic currency. The realized bank profit from lending in $F$ after regulation is zero for both realized exchange rates and completely insensitive to the exchange rate (since no lending occurs). Balancing this reduction in bank exposure to FX risk, investors increase their lending in $F$, and therefore increase their equity's sensitivity to FX risk. The exposure of firms that still receive FX funding is unchanged, but some firms no longer receive FX funding. As a result, the net effect is only a small reduction in firm sensitivity to currency movements (and less of a reduction than occurs for banks).

\section{Testable implications of the model}

This section has developed a stylized model of informed bank and uninformed market lending in domestic and foreign currency. This model yields four testable implications about the effects of FX macroprudential regulation of banks:

(1) Banks borrow and lend less in foreign currency (but do not change their borrowing in domestic currency). 
(2) Some firms shift away from banks to increase their FX borrowing from market investors (with no increase in non-FX borrowing by firms and banks).

(3) Banks' exposure to exchange rate movements declines significantly.

(4) Firms' exposure to exchange rate movements declines moderately, and by less than that for banks.

\section{E. An extension with exporters}

In an effort to keep the model parsimonious and focus on the key channels that are the focus of the empirical analysis, we do not explicitly differentiate between smaller, more domestically-focused firms and larger, export-oriented firms. This differentiation could be important, however, if exporting firms have a natural hedge against currency movements and are therefore be more likely to obtain cheap funding in foreign currency, irrespective of whether macroprudential FX regulations are in place. ${ }^{16}$ Therefore, we have also developed a version of the model to incorporate this scenario.

More specifically, evidence suggests that exporters tend to be larger and more productive than non-exporters (e.g., Bernard et al., 2003, Melitz, 2003), so we extend our framework to assume that some high-productive firms are exporters. A fraction of their output $A_{H}$ is a good that is priced in $F$, offering a natural hedge against FX risk. The status of exporters is publicly observable, so investors can infer that these firms have high productivity. Hence, the competitive lending rate is $\rho_{E}^{*}=r_{F}$. This cost of market funding in $F$ to exporters is cheaper than bank funding in either currency, so exporters prefer to obtain funding from investors in $F$-irrespective of macroprudential $\mathrm{FX}$ regulation.

All of the key implications from the model developed above continue to hold, except that now exporters default less often after a depreciation of the domestic currency. This lower default probability is partly due to their natural hedge (with a share of production priced in $F$ ), and partly due to their cheaper funding. Specifically, for an intermediate depreciation $e_{L} \in\left[\underline{e_{L}}, \widehat{e_{L}}\right]$, where $\underline{e_{L}} \equiv \frac{r_{F}-\phi A_{H}}{(1-\phi) A_{H}}$, an exporting firm does not default after having received market funding in $F$, but would have defaulted after receiving bank funding in $F$.

\footnotetext{
${ }^{16}$ For example, Kalemli-Ozcan et al. (2016) show that exporters have a higher share of dollar debt than non-exporters
} in Latin American firms. 


\section{The Data}

This section discusses the data used for the empirical analysis. It is divided into two parts. The first provides details on the newly compiled dataset on macroprudential FX regulations that is central to this paper. The second discusses the additional explanatory and control variables used in the analysis.

\section{A. Data on Macroprudential FX Regulations}

We define macroprudential FX regulations as regulations that discriminate based on the currency denomination of a capital transaction. ${ }^{17}$ Macroprudential FX regulations usually focus on the domestic banking system and can be implemented by the government, the central bank, or the national prudential regulator. Our measures of macroprudential FX regulations do not include capital controls-which discriminate by the residency of the parties involved in the transaction-although there is substantial overlap in these two types of measures given that transactions between residents and non-residents are more likely to involve FX. Also, while our measures are macroprudential, as they are directed at systemic risks to the entire financial system stemming from FX flows and exposures, some measures (such as sectoral FX capital risk weights) can also be classified as microprudential regulations (which generally target the resilience of individual financial institutions).

To construct our database, we draw on four sources on macro-prudential regulations: Shim et al. (2013), Vandenbussche et al. (2015), Cerutti et al. (2017), and Reinhardt and Sowerbutts (2018). Each of these datasets uses different sources and has a different focusbut includes some information on macroprudential FX regulations. More specifically, Shim et al. (2013) provides verbal descriptions of policy events broadly related to the housing sector for 60 countries at a monthly frequency from 1990-2012. Vandenbussche et al. (2015) provides detailed data on a broad range of macroprudential policy actions for 16 countries from Emerging Europe over the period 1997-2010. Cerutti et al. (2017) uses an IMF database on country surveys to provide measures for 12 macroprudential policies, including on FX- and local-currency reserve requirements, in a set of 64 countries over 2000-14. Finally, Reinhardt and Sowerbutts (2018) build a database on macroprudential policy actions for 60 countries starting in 1995. For more details on the construction of this dataset on macroprudential FX

\footnotetext{
${ }_{17}$ Throughout the paper, we use the terms "macroprudential FX regulations" and "FX regulations" synonymously.
} 
regulations, see Appendix A in Ahnert et al. (2018).

After combining these sources, our dataset includes information on 132 changes in macroprudential FX regulations from 1995 through 2014 (on a quarterly basis) that represent either a tightening or loosening in regulation. This full sample includes both advanced and emerging economies, but we exclude reserve-issuing countries (i.e., long-standing members of the Euro Area, the US, Switzerland and Japan) to focus on countries more vulnerable to currency mismatches and the global financial cycle. We also exclude offshore centers, as defined by the BIS in International Banking Statistics, with the exception of Singapore and Hong Kong. This leaves us with a sample of 48 countries for our main empirical analysis. ${ }^{18}$ Some countries have made no changes to macroprudential FX policy, while others have made more than ten. There is good coverage of countries in Asia, Europe, and South America, but coverage is more limited for the Middle East and Africa. ${ }^{19}$

Figure 1 shows the cumulated changes in all macroprudential FX regulations from 1995 through 2015. Any adoption or tightening of each regulation in the dataset is counted as a +1 , and any reduction or removal is a -1 , with the graph showing the cumulated total on the given date. The figure shows a general trend of tightening FX regulations since the mid-200os, interrupted by a brief period of loosening during the Global Financial Crisis. In our dataset, these macroprudential FX regulations can be further disaggregated into those focusing on banks' FX assets and those on banks' FX liabilities. ${ }^{20}$ More specifically:

- FX Asset-side Measures (in blue) include all policies aimed at the FX assets of domestic banks. These generally focus on restricting FX lending to corporates and households in the domestic economy. These measures include FX capital regulations for banks (such as provisioning rules or risk weights associated with FX-lending). These also include lending standards for FX loans, incorporating both quantitative lending standards (such as loan-to-value (LTV) ratios or debt-to-income (DTI) ratios for FX loans), and qualitative lending standards for FX loans (such as amortization requirements for FX loans).

\footnotetext{
18 The full list of countries is reported in Table A1 in Ahnert et al. (2018), with the cumulated number of changes in each type of macroprudential regulation by country.

19 Our sample includes 17 advanced economies and 31 emerging markets (as classified by the BIS in their International Banking Statistics). Advanced economies increased their use of FX regulations towards the end of the sample, but emerging markets account for the vast majority of FX regulatory actions.

20 These two categories can be further disaggregated into various subcategories. We do not focus on the more detailed disaggregation in this paper, however, as the sample size becomes too small to yield meaningful results.
} 
- FX Liability-side Measures (in red) include all policies aimed at the FX liabilities of domestic banks. These measures generally focus on the funding decisions of banks and include FX reserve requirements and FX liquidity requirements (such as liquidity coverage ratios or taxes on non-core FX liabilities). These measures tend to specifically target FX flows with a short maturity.

The shaded areas in Figure 1 show the cumulated actions for these two types of FX measures, with 30 cumulated liability-side regulations and 37 cumulated asset-side measures at the end of the sample period. Asset-side FX regulations started to be adopted more rapidly just before the global financial crisis, and then experienced another surge around 2010-11, but have since been adopted at a more moderate pace. Liability-side FX regulations were adopted more gradually from 2002-2006, after which use fell by about half, until after 2010 they regained attention and their use roughly doubled during 201013. These different types of macroprudential FX regulations could have different effects on the economy. For example, measures targeting banks' FX liabilities might affect their FX lending to all their borrowers, while asset-side measures might only restrict FX lending to specific borrowers (for example those lacking a natural hedge).

For a final cut of the data, Figure 2 uses the same categories to break out the number of times each macroprudential FX measure was either tightened or loosened. This is useful to better understand what is driving the cumulated statistics in Figure 1, as "no change" in the cumulated graphs could mask no change in the given regulation by any country, or a number of countries which tightened the measure while an equal number simultaneously loosened. Figure 2 shows that, in many periods, the latter is the case-with some years when a large number of countries simultaneously tightened and loosened different policies. Figure 2 also provides more detail on the phases of tightening and loosening in macroprudential FX regulations shown in Figure 1.

\section{B. Data on International Capital Flows and other Variables}

This section begins by discussing the international capital flow variables on bank and corporate borrowing that will be the focus of the empirical tests. It closes with a discussion of the various control variables.

To begin, in order to test model prediction \#1 on the impact of FX regulations on crossborder loans to banks, we use quarterly data from the BIS International Banking Statistics 
(IBS), which reports both FX and non-FX gross capital inflows to banks. These data are expressed as a percent of annual GDP (calculated as 4-quarter moving averages). ${ }^{21}$ In order to test model prediction \#2 on the spillover effects of the regulations, we use data from the BIS International Debt Statistics (IDS), which includes debt securities issued by domestic headquartered companies on international markets in FX and non-FX.

Figure 3 graphs several of these measures which will be a focus of the empirical analysis. Figure 3 a shows the evolution of cross-border loans to banks as a percent of GDP, broken into loans in FX (red) and non-FX (blue). This shows the decline in cross-border lending since around the crisis, with basically all of the decline occurring in FX lending. Figure $3 \mathrm{~b}$ shows international debt issuance over the same period, also broken down into FX (solid lines) and non-FX borrowing (dashed lines), and further distinguished into borrowing by banks (green) and corporates (orange). This shows that international debt issuance in FX has increased fairly steadily since the crisis for corporates, but fallen for banks. Non-FX borrowing by corporates has been fairly flat, and for banks has decreased. These graphs are only suggestive, but the trends agree with the model's prediction; after a tightening in macroprudential FX regulations (such as after the 2008 crisis), cross-border FX lending by banks declines (with no change in non-FX lending by banks), while corporate debt issuance in FX increases (with no increase in corporate non-FX debt issuance or bank debt issuance in FX or non-FX).

The empirical analysis also includes a number of control variables that merit discussion. These variables were chosen to be consistent with existing literature, most closely following recent work on the determinants of cross-border bank flows in Avdjiev et al. (2016a) and Bruno and Shin (2016). An innovation in our control variables is that when we calculate the exposure of country $i$ to certain variables in other countries, we weight the respective variable by country is "financial exposure" instead of its trade exposure. As shown in Lane and Shambaugh (2010) and Bénétrix et al. (2015), this can be important when countries have different currency than trade exposures (such as many emerging markets which are more exposed to US dollar movements than predicted based purely on trade patterns). A sensitivity test shows that this weighting does not impact the key results.

We include five variables in our baseline specification, focusing on variables with some time variation so that they are not absorbed in the country fixed effects. These controls are:

${ }^{21}$ In the BIS banking statistics, capital 'flows' are calculated as estimated exchange rate-adjusted changes in stocks; therefore they should not be affected by exchange-rate valuation effects. See Appendix A of this paper. 
- Changes in non-FX macroprudential regulation: measured by calculating any change in macroprudential regulations in the four datasets discussed above (from Shim et al., 2013; Vandenbussche et al., 2015; Cerutti et al., 2017; and Reinhardt and Sowerbutts, 2018) for country $i$. Then any changes in FX regulations are removed. The resulting measure is reported as +1 for any new use/tightening of any non-FX macroprudential regulation, and a 1 for any reduction/removal. The variable is the sum of its contemporaneous effect as well as three lags. Appendix A in Ahnert et al. (2018) discusses the compilation in more detail.

- Real GDP growth: measured as quarterly real GDP (yoy) growth based on IMF statistics. This is a standard control to capture changes in country-specific returns.

- Exchange rate volatility, weighted based on country financial exposure: calculated as: $=s t d_{t}\left(\sum w_{n, t}^{F} \cdot \Delta e_{n, t}^{F}\right)$, where $s t d_{t}()$ is the standard deviation at quarterly frequency and $\Delta e_{n, t}^{F}$ is the weekly change in the bilateral exchange rate between the domestic economy and foreign country $n$. This controls for the relative riskiness of FX- versus non-FX loans (see Rosenberg and Tirpak, 2009 and Brown and De Haas, 2012).

- Interest rate differential, weighted based on country financial exposure: calculated as $=i_{t}^{D}-\sum w_{n, t}^{F} \cdot i_{n, t}^{F}$, where $i_{t}^{D}$ is the domestic $(D)$ nominal interest rate in quarter $t ; w_{n, t}^{F}$ is the (annual) financial weight of foreign $(F)$ country $n$ in quarter $t ; i_{n, t}^{F}$ is the foreign interest rate of country $n$ in quarter $t$, and $n$ captures the major currencies/currency areas (USD, GBP, EUR, YEN, CHF). This controls for the return/funding costs of FX loans relative to the return/funding costs of non-FX loans. ${ }^{22}$ The weightings place more weight on the relative funding differentials for the most relevant countries/regions.

- Sovereign rating: measured as the change in sovereign rating, based on data from Trading Economics in order to capture any changes in country-specific risk.

- Financial openness: measured using the Chinn-Ito (2008) index of financial openness. This is a standard control to capture any capital controls or other factors affecting the ease by which banks or firms can borrow internationally.

Additional details on these independent variables are provided in Appendix A.

${ }^{22}$ For evidence, see Rosenberg and Tirpak (2009), Brown and De Haas (2012), and Brown et al. (2014). 


\section{Empirical Results: Direct Effects and Leakages of Macroprudential FX Regulations}

This section formally tests how macroprudential FX regulations affect different components of capital inflows, building on the theoretical framework developed in Section II. It begins by developing the specification that will be used for the remainder of the section. Then it reports the central results on how macroprudential FX regulations affect various types of capital flows in domestic and foreign currency for banks and corporates. For this baseline analysis, we aggregate the different types of macroprudential FX regulations. The section ends with tests for different effects of the disaggregated measures of macroprudential regulations. It is worth noting that a key aspect of this series of tests is not just the effects of macroprudential FX regulations on certain types of capital flows (such as bank borrowing in FX), but also whether there are no effects on other types of capital flows (such as bank borrowing in non-FX). These "non-effects" suggested in the empirical model are also an important a part of the hypothesis testing and provide a useful check that any results are not driven by omitted variables that would affect all types of capital flows.

\section{A. Estimation Framework}

To test the first two predictions on how macroprudential FX regulations affect bank and corporate borrowing in domestic and foreign currency, we use a cross-country panel regression framework with country- and time-fixed effects. We control for domestic and global factors over time, similar to the specifications used to predict international capital flows (or just international banking flows) in Forbes and Warnock (2012), Bruno and Shin (2016), and Avdjiev et al. (2016a). More specifically, our baseline equation is:

$$
F_{i, t}=\alpha+\sum_{k=0}^{3} \beta_{1} \operatorname{fxm}_{i, t-k}+\gamma^{\prime} X_{i, t-1}+\delta_{i}+\delta_{t}+\varepsilon_{i, t},
$$

where $F_{i, t}$ is the measure of quarterly gross cross-border capital inflows for the respective sector of country $i$ (discussed in Section III.B). ${ }^{23}$ The variable $f x m_{i, t-k}$ captures changes in macroprudential FX measures (discussed in Section III.A), expressed as a dummy variable

\footnotetext{
${ }^{23}$ Quarterly capital inflows are scaled by annual GDP, which is calculated as a 4-quarter moving average of annual data to avoid breaks due to annual GDP rising or falling from Q4 to Q1. We scale by annual GDP rather than quarterly GDP because the sum of the contemporaneous coefficient and three lags on $f x m_{i, t}$ reported in the regression tables can then be read as the effect on capital flows to annual GDP over a one year period.
} 
that takes the value of +1 if restrictions on FX lending or borrowing are tightened (and -1 if they are loosened). To account for potential time lags in the impact of these policies, we include the contemporaneous value of $f x m_{i, t}$ as well as its three lags, and evaluate their joint effect by testing if the sum of all four coefficients is significantly different than zero. $X_{i, t-1}$ is a set of control variables (discussed in Section III.B); $\delta_{i}$ are country-fixed effects and $\delta_{t}$ are global time effects. The sample period is 1996 Q1- 2014 Q4.

Several details of this specification and variables merit further discussion. ${ }^{24}$ First, the left-hand side variable, $F_{i, t}$, is measured in several different ways in order to test the different predictions of the model and better understand the direct and indirect effects of the macroprudential FX regulations. More specifically, in order to test model prediction \#1 on the impact of the regulations on cross-border loans to banks, $F_{i, t}$ is measured as FX or non-FX gross capital inflows to banks, as well as the FX share of total capital inflows to banks. In order to test model prediction \#2 on the spillover effects of the regulations, $F_{i, t}$, is measured as FX and non-FX net international debt issuance by corporates and banks, as well as the change in the FX share of total net debt issuance by each group. (Extensions also consider the impact of regulations on total loans to banks and total debt issuance by corporates.)

A second noteworthy feature of equation (16) is the measure of macroprudential FX regulation, $f x m_{i, t-k}$. This is measured as a dummy variable capturing the changes in macroprudential FX regulations and discussed in more detail in Appendix A of Ahnert et al. (2018). In our main analysis, this aggregates all of the different types of macroprudential FX regulations, but in some extensions it only includes changes in FX regulations targeting bank assets or those targeting bank liabilities, disaggregated as discussed in Section III.A.

A final important point in equation (16) is the time fixed effects $(\delta t)$, which are included to control for all global factors common across countries in each period. These global factors have been shown to be an important driver of global capital flows, such as in Forbes and Warnock (2012), Rey (2013), and Avdjiev et al. (2016a), but there are different views on which factors are most important (such as the role of global risk or monetary policy in advanced economies). By controlling for a global-time fixed effect, we do not need to take a stance on

24 To ensure that large observations are not driving the results, all dependent and independent variables are winsorised at the $2.5 \%$ level (except for variables based on bounded indices). In order to account for exchange rate valuation effects, changes in shares are calculated based on a series of stocks calculated by adding cumulated exchange rate adjusted changes in bank loans and deposits or net issuance of debt securities to initial stocks. Before winsorising the resulting shares, we exclude changes in shares above $+100 \%$ or below $-100 \%$. 
exactly which global factors are important, or worry about time effects shared by all countries that are difficult to measure. To show that this assumption does not affect our main results, however, we also report tests where we include standard global variables that have been shown to be associated with global capital flows (such as global volatility, global growth, and changes in US monetary policy) instead of this common global-time fixed effect. These different specifications of global factors have no meaningful impact on the key results.

All the independent variables are lagged by one quarter (or by one year in the case of GDP growth) to reduce endogeneity concerns. Additional details on each of these independent variables are provided in Appendix A.

\section{B. Baseline Results: Direct and Spillover Effects of Macroprudential FX Regulations}

To test these predictions, Table 1 begins by testing for the effects of FX regulations on gross cross-border loans from international banks to domestic banks-using the specification in equation (16) and the data discussed in Section III. According to Hypothesis \# 1, increased macroprudential FX regulations should reduce the volume of FX borrowing and share of FX borrowing by banks, with no significant effect on banks' non-FX borrowing. The first three columns report reduced-form results with no control variables, columns (4) through (6) report results with the full set of controls discussed in Section III (plus the global-time dummies), and columns (7) through (9) report results with explicit controls for global factors (global volatility, global growth, and changes in US interest rates), instead of the global-time fixed effects. ${ }^{25}$ Each set of three columns repeats the analysis for the same three variants of the dependent variables for each specification (FX capital inflows, the share of FX inflows in total inflows, and non-FX inflows), a pattern repeated in each set of our tests for the respective variables. Also, to simplify an interpretation of the results, the coefficients on macroprudential FX regulations and non-FX regulations are reported as the sum of the quarterly coefficient estimates $\left(\sum_{k=0}^{3} \beta_{1}\right)$, with a reported $p$-value to indicate if the sum is jointly significant. These are written in italics, with no parentheses around the $p$-values, to clarify that this is distinct from the other coefficient estimates reported with standard errors (in parentheses).

The coefficient estimates in Table 1 support the predictions on how macroprudential FX regulations affect international borrowing by domestic banks. Tighter macroprudential FX

25 The global variables follow the capital flow literature, such as Forbes and Warnock (2012) and Avdjiev et al. (2016a). 
regulations are correlated with a significant decrease in foreign currency borrowing by banks and in the FX share of total international borrowing by banks, over the subsequent year. To put the magnitude of these estimates into context, cross-border FX loans to banks fall over a one-year period by $0.50 \%-0.66 \%$ of GDP following a tightening in FX regulations. This suggests the effect of macroprudential regulations on cross-border FX loans to banks is large and meaningful. FX loans are around $1.9 \%$ of GDP at the median of our sample (across quarters when inflows were positive), suggesting that tighter FX regulations corresponds to a decline in FX cross-border loans by banks of about one-third. Or, to put this in the context of individual countries, consider Brazil and Indonesia-two countries which have been concerned about FX exposure. In both countries, FX loans to banks are a little less than $1 \%$ of GDP, suggesting that an increase in macroprudential FX regulations corresponds to a reduction in FX loans to banks by over half.

In contrast, and as also expected, the increase in macroprudential FX regulations does not have a significant effect on non-FX borrowing by banks (columns 3, 6, and 9). Banks do not significantly increase their borrowing in local currency to compensate for their reduced borrowing in FX. Corresponding estimates for the impact of macroprudential FX regulations on total international borrowing by banks (not reported) show that the aggregate effect is weakly negative-as expected-but only significant at the $10 \%$ level. This suggests that the reduction in international FX borrowing by banks after tighter regulations is not fully compensated for by increased non-FX borrowing.

The other coefficient estimates in Table 1 generally have the expected sign, albeit with mixed significance. ${ }^{26}$ The coefficients that are most often significant are those on GDP growth and sovereign ratings-which suggest that faster growth and higher ratings are significantly correlated with increased capital inflows, especially in foreign currency. The global variables also have the expected signs in columns (7) through (9), with lower volatility, higher global growth, and lower US interest rates correlated with stronger FX borrowing by banks. The other results are basically unchanged when these global control variables are included, suggesting that their effects are largely captured in the global-time effects (in columns 1-6).

Next, Table 2 follows the same format as Table 1, except now tests how macroprudential FX regulations affect international debt issuance by domestic corporations (Hypothesis \#2).

\footnotetext{
${ }^{26}$ An increase in non-FX macroprudential regulations is usually positively associated with cross-border inflows, albeit generally insignificant. This could indicate that increased regulation increases confidence in the financial system and thereby supports greater inflows, as tentatively found in Reinhardt and Sowerbutts (2015) and Forbes et al. (2015).
} 
The coefficient estimates on macroprudential FX regulations in Table 2 again have the predicted effects. Tighter macroprudential regulations are correlated with a significant increase in foreign currency debt issuance by corporates, and a significant increase in the share of corporate debt issued in FX by corporates, with no significant effect on non-FX debt issuance. The magnitude of these effects continues to be economically meaningful, albeit substantially smaller than that of increased regulations on international bank flows. More specifically, international debt issuance by corporates increases by $0.05 \%$ to $0.06 \%$ of GDP following a tightening in FX regulations. This suggests the effect of macroprudential regulations on cross-border FX corporate debt issuance is moderate, given that net FX debt issuance is around $0.6 \%$ of GDP (at the sample median when net FX debt issuance was positive). For some countries, however, the impact is substantially larger. For example, in Brazil and Indonesia FX debt issuance is $0.26 \%$ and $0.36 \%$ of GDP, respectively, suggesting that tighter FX regulations correspond to roughly a $15 \%$ to $20 \%$ increase in this issuance.

Combining the results of Tables 1 and 2 allows us to assess the aggregate effects of an increase in macroprudential FX measures on country exposure to FX risk through banks, as well as the degree of "shifting snowbanks" (i.e., the substitution of FX exposure from banks to investors who hold the new FX corporate debt issuance). This shifting of FX risk can be calculated as the ratio of net FX debt issuance by corporates to international FX loans to banks. This ratio indicates that after an increase in FX regulations, about $10 \%$ of the decline in FX exposure in banks shifts to corporate debt issuance (and thereby to investors and other non-bank financial institutions). ${ }^{27}$ This suggests that even though increased macroprudential FX regulations on banks leads to some "shifting snowbanks" of currency risk to other sectors of the economy, namely investors in our framework, there is still a meaningful net reduction in aggregate $\mathrm{FX}$ borrowing in the economy.

To complete the hypothesis testing and better understand the full set of relationships for which data is available (including those not formally included in the model), Appendix Table B1 reports several additional results. Columns (1) through (3) test for any impact of FX regulations on cross-border loans to non-banks. Although this data includes loans to nonbank financial institutions as well as corporates, and therefore does not exactly test the

\footnotetext{
${ }^{27}$ Another way to calculate this ratio would be to adjust for the fact that not all FX lending by banks goes to corporateswith recently enhanced BIS data showing that on, average, $62 \%$ of FX loans from banks to non-banks are lent to the corporate sector (with the remainder lent to households, government and non-bank financials). Taking this into account, the "shifting" effect of FX exposure would be about 13\% (instead of 10\%). This new BIS data, however, is only available for limited countries (Canada, Cyprus, Denmark, United Kingdom, Korea, Sweden and South Africa).
} 
channel in the model (which only focuses on corporates), it finds no significant effect of FX regulations on cross-border loans to non-banks. This would agree with the model's prediction of no significant effect on cross-border loans to corporates.

Next, we examine the impact of macroprudential FX regulations on domestic lending by banks to corporates. The theoretical model suggests that domestic lending by banks in FX should decline (corresponding to the reduction in bank cross-border funding in FX), with no significant decline in domestic bank lending in domestic currency. Unfortunately, our lending dataset only includes cross-border capital flows and does not have information on domestic lending. Therefore, to test this channel, we use enhanced BIS data that provides information on domestic lending in both local and foreign currencies. ${ }^{28}$ This data, however, has several limitations: it only begins in 2012Q3 (thereby truncating our sample in roughly half); it only covers $30 \%$ of the countries in our sample; and it is only available for lending to non-banks (which includes non-bank financials) and not just corporates (as in the model). With these important caveats, the results in columns (4) through (6) of Appendix Table B1 support the main predictions of the model. ${ }^{29}$ An increase in FX regulations corresponds to a significant reduction in FX domestic lending by banks to non-banks (largely corporates) over the next year, with no significant effect on non-FX lending by banks to non-banks. ${ }^{30}$

Finally, as an additional set of tests to "complete the story", columns (6) through (9) of Appendix Table B1 report estimates of the effect of increased FX regulations on international debt issuance by banks. The estimates find no significant effect at the $5 \%$ level of increased FX regulation on international debt issuance by banks-whether measured as foreign currency issuance, the FX share of issuance, or domestic currency issuance. This supports the model's predictions, and sharply contrasts with the results for corporate debt issuance (a significant positive effect of macroprudential FX regulations on FX issuance). If anything, Table B1 suggests that there may be a weakly negative effect for bank debt issuance-albeit only significant at the $10 \%$ level for FX inflows. This weakly negative impact on bank FX debt issuance may reflect the overall reduction in bank exposure to FX risk after increased FX regulations. It is unsurprising that banks reduce this risk more through loans than net debt issuance, however, as bank loans tend to be shorter-term in maturity than debt securities, and

\footnotetext{
28 This is a relatively new series in their International Banking Statistics.

29 The specification and control variables are the same as in Table 1 and the other columns in Appendix Table B1, except with robust standard errors (instead of clustering by county) due to the much more limited sample.

$3^{0}$ The coefficient on the share of FX lending is negative (as expected), but insignificant. This reflects the small decline in non-FX domestic lending, mitigating the impact on the ratio of FX lending.
} 
FX regulations primarily target debt/loans at shorter maturities.

This combination of results provides evidence that macroprudential FX regulations have the intended direct effect of decreasing bank borrowing in FX, but also have the unintended consequence of causing corporations to take on more international debt in foreign currency. The fact that corporations do not simultaneously increase international debt issuance in domestic currency, and that banks do not significantly increase debt issuance in any currency, also suggests that these results are not capturing some type of omitted variable that would lead to a general increase in international borrowing or debt issuance in foreign currency. Macroprudential FX regulations only correspond to an increase in corporate FX debt issuance-but not an increase in other forms of international corporate borrowing (through debt or bank loans), nor bank corporate debt issuance.

\section{Macroprudential FX Regulations: The Role of Type and Magnitude}

Macroprudential FX regulations appear to effect international borrowing and debt issuance. But do different types of macroprudential FX regulations have different effects on banks and corporates? The theoretical model shows that regulations targeting the liabilityside of bank balance sheets (i.e., aimed at raising the cost of FX funding of domestic banks) work through somewhat different channels than those targeting the asset-side (i.e., aimed at raising the cost of bank FX lending to households and corporates in the domestic economy). This section tests for any differential effects of the various forms of macroprudential FX regulations. These results should be interpreted cautiously, however, as these finer divisions of different forms of macroprudential FX regulations imply that there are more limited degrees of freedom for the analysis.

To begin, we focus on any differential effects if the FX macroprudential regulations target banks' assets or liabilities, using the definitions discussed in Section III.A. ${ }^{31}$ Results are shown in Table 3, which repeats the baseline framework from Tables 1 and 2, with the full set of control variables and global-period dummy variables. ${ }^{32}$ The results are similar for assetand liability-based measures when assessing the effect on cross-border loans to banks, but differ when assessing the impact on FX debt issuance by corporates. More specifically, both asset- and liability-side FX measures are correlated with a significant decrease in FX

${ }^{31}$ We have also examined effects using narrower definitions of FX regulations, but the number of regulatory actions quickly becomes so limited that results become sensitive to minor changes in specification and country inclusion.

$3^{2}$ Results are basically identical when the individual global variables are included instead of the global-time dummy. 
borrowing by banks - with the magnitude of the coefficient estimated to be larger for assetside regulations, but only significant at the $10 \%$ level in column (8). For both measures, FX regulations continue to have a positive effect on FX debt issuance by corporates-but this effect is only estimated to be significant (at either the $5 \%$ or $10 \%$ level) for liability-side regulations. The magnitude of the coefficient on FX debt issuance is also estimated to be about three times larger for liability-side than asset-side regulations (In both cases, there continues to be no significant effect on non-FX debt issuance by corporates and banks.).

These results suggest that both asset- and liability-side FX measures are effective in their direct goal of reducing cross-border loans to banks in FX. Only the liability-side measures, however, may also have the unintended side-effect of increasing FX debt issuance by corporates. Repeating the calculations to gauge the degree of "shifting", an increase in liability-side FX measures causes FX debt issuance by corporates to increase by $16 \%$ of the reduction in FX loans by banks (instead of 10\% when all FX regulations are aggregated). ${ }^{33}$ In other words, liability-side regulations appear to cause more "shifting snowbanks" of currency vulnerability from banks to other sectors. As a result, asset-side regulations may better improve a country's resilience to currency movements, as they decrease bank exposure to currency risk but simultaneously generate less shifting of this risk to other sectors.

One possible reason for these differential effects, as suggested in the theoretical model, is that liability-based measures affect all forms of bank funding in all states of the world. In contrast, asset-based measures only affect bank lending, and often only certain segments of bank lending (such as through mortgages) - thus affecting a smaller share of bank balance sheets and having a smaller aggregate effect. Closely related, if asset-side regulations primarily affect bank lending to households, while liability-side regulations affect lending to both corporates and households, it is natural that tighter liability-side FX regulations correspond to a greater response in the corporate sector. Supporting this hypothesis, in some countries most FX regulations target the asset-side, a large share of which are regulations on LTV ratios, DTI ratios, and other aspects of FX lending for mortgages (such as in Hungary and Poland). A final possible explanation is the maturity of the capital flows targeted by these different measures. FX liability-based measures tend to focus on shorter-term inflows, while FX assetbased measures tend to focus on longer-term maturities. As macroprudential measures often

33 This is calculated as 0.0788 (Table 3, column 4) divided by 0.487 (Table 3, column 1). If one also incorporates that only about $62 \%$ of FX loans from banks to non-banks are likely lent to the corporate sector, the degree of shifting increases to $26 \%$. 
involve a greater relative cost for short-term than longer-term capital flows, these shorterterm flows are the ones most affected.

Macroprudential FX regulations could have different effects based not only on whether they target assets or liabilities, but also based on how large the change in the regulation is. Assessing the intensity of changes in macroprudential regulation is difficult, however, because most data on macroprudential regulations only records whether the regulation is tightened or loosened using dummy variables (as in our data set). This is the standard treatment in the literature, because it is impossible to compare discrete changes in different types of regulations (i.e., a 10\% increase in FX reserve requirements is unlikely to correspond to a 10\% increase in the FX liquidity coverage ratio). It is even difficult to compare changes of the same magnitude in a specific FX regulation across countries, given different definitions and coverage (i.e., a 10\% increase in the liquidity coverage ratio can mean very different things based on the country's definition of what qualifies as a liquid asset). A few papers have shown that having more macroprudential measures in place or "major" changes in regulations generate larger effects, results that are intuitive but do not provide concrete information on how a given change in a regulation would be expected to affect a key outcome variable. 34

In an effort to move beyond this standard treatment of macroprudential regulations, we extend our analysis to estimate the impact of concrete changes in specific regulatory instruments. More specifically, we focus on two databases which provide information on the intensity of macroprudential FX policies, albeit in a limited sample or for a limited set of measures. First, Cerutti et al. (2017) includes data with information on the intensity of FX reserve requirement changes for a sample similar to ours. 35 Second, Vandenbussche et al. (2012) includes information on the intensity of other types of regulations: foreign currency liquidity requirements, the maximum ratio of foreign currency loans to own funds, risk weights on foreign currency mortgage loans, consumer loans and corporate loans. These more detailed data, however, have two important disadvantages: the data ends in 2010 (thereby missing a period of active use of macroprudential FX regulations) and the data is only available for Eastern Europe (thereby severely limiting country coverage).

\footnotetext{
34 More specifically, Cerutti et al. (2017) create a measure which is the sum of the number of different types of macroprudential measures in use. Forbes et al. (2015) classify a subset of their measures of capital controls and macroprudential measures as those which were "major", based on the attention by investors, financial analysts, or international financial institutions (as assessed by coverage in analyst reports, IMF papers, and surveys).

35 Specifically, the authors state that given the mostly quantitative nature of reserve requirements, values above or below 1 and -1 for their index can capture the intensity in the changes (with the index ranging from -3 to +5 ).
} 
Keeping these caveats in mind, the resulting estimates give some idea of the magnitude of the effects from these specific FX regulations. First, a large increase in reserve requirements on foreign currency borrowing (proxied by the quantitative index taking a value of 5) leads to a decline in FX loans to banks by $0.46 \%$ of GDP and an increase in FX international debt issuance by $0.15 \%$ of GDP. Second, an increase in the foreign currency liquidity requirement by 10pp reduces FX loans to banks by $2.9 \%$ of GDP and increases international FX debt issuance by corporates by $0.36 \%$ of GDP. Third, a tightening in the maximum ratio of FX loans to own funds from $400 \%$ to $200 \%$ reduces FX loans to banks by around $1 \%$ of GDP and increases FX debt issuance by corporates by $0.05 \%$ of GDP. Finally, an increase in the risk weight on foreign currency mortgage loans, consumer loans or corporate loans by 5opp above the local currency risk weights reduces FX inflows to banks by $0.26 \%, 0.46 \%$ or $1.83 \%$ of GDP, respectively, and corresponds to an increase in FX international debt issuance by corporates by about $0.07 \%$ of GDP in each case. All of these estimated effects of specific changes in FX regulations have the expected sign, and several of the estimates (such as for foreign currency liquidity requirements) are consistently significant despite the limited sample size. ${ }^{36}$

\section{Endogeneity and Other Sensitivity Tests}

The finding that macroprudential FX regulations significantly reduce bank borrowing in FX and increase corporate debt issuance in FX are central to understanding the impact of these regulations, so we next perform a series of robustness checks, including specifications that should better identify the exogenous component of macroprudential regulations. For each test, we focus on whether macroprudential FX regulations decrease international bank borrowing (or share of borrowing) in FX and non-FX, and whether they increase corporate debt issuance (or share of debt issuance) in FX and non-FX (Tables 1 and 2, respectively). We do not report all of the "non-results" that are not significant (nor expected to be significant), as they continue to be insignificant in all of the tests discussed below.

One potential concern with the baseline analysis is that trends in our dependent variables could be driving changes in macroprudential policy instead of vice-versa (i.e., endogeneity). ${ }^{37}$ For example, increased corporate debt issuance in FX could heighten concerns about risks to domestic financial stability related to aggregate FX exposure, causing policymakers to tighten

\footnotetext{
${ }^{36}$ Detailed results are available on request. Each of these estimates are based on regressions using the same format as the baseline regressions in Tables 1 and 2, including all of the control variables and global time effects.

37 Omitted variable bias is also a frequent concern in cross-country empirical papers, as some hard-to-measure variables could simultaneously affect cross-border capital flows and FX regulations. This is less of a concern in our framework, however, due to the tests for "non-results" corresponding to our main results (as in Section IV.B).
} 
regulations on banks' exposure to FX and thereby reduce aggregate FX exposure and/or bank lending in FX. To better control for endogeneity, we adopt an alternative approach that estimates an "exogenous" shock to macroprudential policy, following the approach used in Auerbach and Gorodnichenko (2013) to estimate more exogenous fiscal policy shocks and in Furceri et al. (2016) to estimate more exogenous monetary policy shocks. We estimate a firststage regression of FX regulations on a range of variables that could affect the implementation of these regulations. Then, we use the residuals from this regression, which should be a more exogenous measure of changes in FX regulations, as the explanatory variable in our baseline regressions (instead of using our -1/o/1 measure of changes in macroprudential FX regulations).

Table 4a presents results from these first-stage regressions estimating a more exogenous measure of changes in macroprudential FX regulations based on a range of models and data sources. $3^{8}$ The results in columns (1) through (4) suggest that stronger GDP growth, domestic credit growth, house price growth, increased financial openness, greater use of non-FX regulations, and faster expected GDP growth over the next year are all positively associated with increases in FX regulations. Each of these variables usually has the expected sign, but most are not individually significant. This captures the well-known challenge of predicting exactly when macroprudential regulations are adjusted. The one exception is the coefficient on exchange rate appreciation, which suggests that larger appreciations consistently correspond to increases in macroprudential FX regulations. Columns (5) and (6) also add lagged values of the dependent variables from our baseline analysis in order to remove any impact of any trends in these variables that could be driving the variation in FX regulation.

Next, we use the residuals from the six different specifications in Table 4a as more exogenous measures of changes in FX regulations in our baseline model in equation (16). Table $4 \mathrm{~b}$ reports the subsequent results (with each column of Table 4 a corresponding to a row in Table 4b) for the key coefficients on FX regulations estimated as in columns 4 and 5 of Tables 1 and 2. The results support the key conclusions from the main analysis; tighter FX regulations correspond to a significant increase in the level and share of cross-border FX loans to banks and a significant decrease in the level and share of cross-border FX debt issuance by corporates. The results are also usually robust across the six different specifications using

38 The selection of variables draws on the limited literature on what determines the use of macroprudential and prudential regulations more broadly, including Cerutti et al. (2015) and Cerutti et al. (2017). 
different variables to predict changes in FX regulations. 39

In addition to these tests that focus on better identifying the exogenous components of macroprudential FX regulation, we also perform additional robustness checks to test for any impact of sample composition, variable definitions, and other factors that could be affecting the key results. Two tests are reported in Appendix Table B2: when offshore centers (Hong Kong and Singapore) are excluded, and when the quarters around the global financial crisis (from 2008Q3 through 2009Q2) are excluded. We have also repeated the analysis when only tightening in macroprudential FX measures are included (not loosening or removals), and when the variables are not financially weighted (as discussed in Section III). Then we drop one country at a time (to exclude any impact from a country with frequent adjustments in regulations). We have also added controls for: the current account balance as a share of GDP (to proxy for net capital inflows), institutional quality, and aggregate financial exposure. $4^{40}$ In this series of tests, the main results discussed above are unchanged and continue to support our main hypotheses. Tighter FX regulation of banks is correlated with banks borrowing less in foreign currency, with no significant effect on their non-FX borrowing. Tighter FX regulation is also correlated with firms increasing their FX debt issuance, substituting away from banks, with no significant effect on firms' and banks' non-FX debt issuance.

Taken as a whole, these results suggest that FX regulations are successful in accomplishing their direct goal - of reducing the FX exposure of banks - but also have the unintended consequence of corporations shifting away from banks and obtaining some FX funding through other sources-primarily through debt issuance in foreign currency to investors. This "shifting snowbank" is only partial, as the reduction in international FX borrowing by banks is larger as a percent of GDP than the estimated increase in FX debt issuance by corporates. Both effects, however, are not only significant, but economically meaningful. The estimates also confirm the various other predictions of the theoretical model, including the variables for which there is not expected to be a significant impact of macroprudential FX regulations, such as on bank cross-border borrowing in domestic currency, and corporate and bank issuance of non-FX debt.

\footnotetext{
39 The only results which are not significant at the $5 \%$ level across all specifications are when house price growth is included in the first stage regressions. The data on house price growth is more limited and restricts the sample size, excluding a number of countries which have changed FX regulations.

${ }^{40}$ Institutional quality is measured by the rule of law and aggregate financial exposure is measured relative to GDP using the Bénetrix et al. (2015) data. Both are described in more detail in Appendix A.
} 


\section{Empirical Results: Macroprudential FX Regulations and Resilience to Currency Movements}

This section assesses how macroprudential FX regulations on banks affect the exposure of banks and the broader economy to exchange rate movements. If the primary motivation of macroprudential FX regulations is to reduce the vulnerability of the economy to sharp currency movements, do the regulations achieve this goal? Does the reduction in FX borrowing by banks significantly reduce bank exposure to currency movements? And if so, through what channels? If bank exposure to currency risk declines, does the exposure largely shift to other sectors of the economy, so that the aggregate vulnerability of the economy is not meaningfully improved?

This section attempts to go one step beyond most other work assessing the direct and spillover effects of macroprudential FX regulations by also testing if the regulations attain one of their ultimate goals: reducing the vulnerability of the economy to exchange rate movements. As discussed in the introduction, there is longstanding evidence of the multifaceted risks and challenges created by exposure to currency movements. If macroprudential FX regulations can mitigate these challenges and risks, they could provide substantive benefits to the broader economy. This approach of testing for the potential effects on country resilience builds on the academic literature identifying ways to increase the effectiveness of regulation in order to strengthen its welfare impact (e.g., Nier et al., 2011, Mendicino et al., 2015, Agénor 2016, and IMF-FSB-BIS, 2016).

\section{A. Empirical Framework and Data}

The theoretical model developed in Section II provides guidance on how macroprudential FX regulations affect the relationship between exchange rate movements and banks' and corporates' stock returns. More specifically, the model yields two hypotheses on the impact of an increase in macroprudential FX regulations: banks' exposure to exchange rate movements declines (so that their stock returns are less sensitive to exchange rate movements) and firms' exposure to exchange rate movements will also decline, but not by as much as for banks. These are testable implications \# 3 and \#4 from the model.

In order to test if macroprudential FX regulations on banks affect bank and corporate 
sensitivity to currency movements, we estimate the following equation: ${ }^{41}$

$$
\begin{aligned}
& \text { seprice }_{i, t}=\alpha+\alpha_{i}+\beta \Delta \text { exrate }_{i, t}+\delta \text { fxm }_{i, t} \\
& +\mu \text { exrate }_{i, t} \times \text { fxm }_{i, t}+\text { controls }_{i, t}+\varepsilon_{i, t} \text {, }
\end{aligned}
$$

where $\Delta$ eprice $_{i, t}$ is, in country $i$ and quarter $t$, the return of a stock market index covering financial sector firms or the corporate sector, respectively (depending on the hypothesis tested). ${ }^{42}$ Next, $\Delta$ exrate $_{i, t}$ is the growth rate of a financially-weighted exchange rate (where an increase is defined as an appreciation of the domestic currency) and $f x m_{i, t}$ is a measure of FX regulation that captures the cumulated policy stance over the current and the last three quarters. ${ }^{43}$ Following Baele et al. (2010), controls $_{i, t}$ contains a set of variables that affect stock returns through channels other than the exchange rate, such as standard macro factors, liquidity factors and risk premium factors, as well as a global volatility index as a proxy for global influences. Finally, $\alpha_{i}$ are country-fixed effects that capture time-invariant differences between countries (e.g., differences in the level of economic or financial development). Details on the sources and construction of the variables are in Appendix A.44

The focus of the analysis is the response of stock returns to a change in the financiallyweighted exchange rate. This is represented by the marginal effect of the exchange rate movement on stock returns, which is a function of the policy stance of the FX regulations:

$$
\frac{\text { eeprice }_{i, t}}{\text { sexrate }_{i, t}}=\beta+\mu \text { fxm }_{i, t}
$$

Our theoretical model shows that an appreciation of the domestic currency leads to an increase in the ex-post profits of banks and corporates, so that $\beta$ is expected to be positive. Furthermore, if FX regulation is effective in reducing the exposure of banks and corporates to exchange rate movements, the coefficient $\mu$ should be negative, so that a tightening of FX

\footnotetext{
${ }^{41}$ In related work, Bruno and Shin (2016) examine how depreciations affect equity prices and Bekaert and Mehl (2017) assess the sensitivity of equity markets to global and regional equity returns.

$4^{2}$ We do not have precise measures of returns for just banks or just corporates. Therefore, we use financial stock returns (which is largely banks) to proxy for bank returns, and we use the overall stock return index (which includes corporates, banks, and non-bank financial institutions) to proxy for corporate returns. To better isolate corporate returns from this broad index, we also construct a series of corporate stock returns. The key results are unchanged.

43 In equation (17), $\mathrm{xxm}_{i, t}$ is measured as the sum of the contemporaneous value of the FX measure plus its three lags. We do not include the contemporaneous value and its three lags separately (as in the analysis in Section IV, equation (16)) to make the calculation of the interaction term in equation (17) straightforward. The smaller country sample in equation (17) also limits the number of lagged and interaction terms that can be included relative to in Section IV. 44 All variables (except global volatility) have been winsorized at the $2.5 \%$ level to reduce the impact of outliers.
} 
regulations (i.e., an increase in $f x m_{i, t}$ ) would reduce exchange rate sensitivity. Since banks are directly affected by FX regulation, however, and corporates can switch to market-based FX borrowing and therefore not reduce their foreign currency borrowing by as much as banks, we would expect the coefficient $\mu$ to be more negative for banks than for corporates.

\section{B. Main Results}

Table 5 presents the results on a sample of up to 24 countries over the period 2000Q1 to 2014Q4. ${ }^{45}$ For most results, we report one set of specifications for financial stock returns (representing banks' stock returns) as the dependent variable and another set for broad market stock returns (representing corporates' stock returns). Columns (1) and (2) only include the three variables central to our exchange rate sensitivity tests, while columns (3) and (4) add standard controls for equity return regressions (the baseline). We will focus on the first three variables in each column: the cumulated FX regulation measure; the financiallyweighted exchange rate (defined so that positive is an appreciation of the domestic currency); and their interaction. The signs of the other control variables are generally similar for financials and the broad market indices and have the expected signs, albeit some have fluctuating significance. ${ }^{46}$

In each of the specifications in columns (1) - (4), the coefficients on FX regulations are insignificant-albeit usually negative and larger for financials-possibly indicating that increased macroprudential FX regulations on banks could reduce bank stock returns. The coefficient on the exchange rate is positive and significant in each case, suggesting that currency appreciation corresponds to higher stock returns (as predicted in the model).

Most important for our analysis, the coefficient on the interaction term (the coefficient $\mu$ in equations (17) and (18)) is negative in each of the four columns. This suggests that increased macroprudential FX regulations reduce the sensitivity of banks and corporates to exchange rate movements. This coefficient, however, is only negative and significant at the $5 \%$ level for bank returns (columns (1) and (3)), and the estimated magnitude of the coefficient is over $50 \%$ larger for banks than corporates in each case. This suggests that macroprudential

\footnotetext{
45 Standard errors are clustered by country. The country sample is limited by the availability of the financial stock returns variable. The countries for which data is available for this analysis are: Australia, Austria, Brazil, Canada, Czech Republic, Denmark, Hong Kong SAR, Hungary, India, Indonesia, Korea, Malaysia, Mexico, New Zealand, Norway, Philippines, Poland, Singapore, South Africa, Sweden, Thailand, Turkey, United Kingdom, and Vietnam.

${ }^{46}$ For example, higher stock returns are correlated with higher industry production growth, lower inflation, a reduction in interest rates, higher stock market turnover, and a lower level of global volatility.
} 
FX regulations reduce banks' sensitivity to exchange rate movements more than that for the broader economy-as predicted.

The magnitudes of the coefficients in Table 5 also provide more information on the size of these effects. Focusing on the columns with the full set of controls in columns (3) and (4), when the cumulated measures of macroprudential FX regulation is neutral, a 1 percentage point depreciation in the financially-weighted exchange rate leads to a decrease in stock market returns for financials by 1.46 percentage points and for the broad market by 1.18 percentage points. When FX regulations are tightened, the same depreciation corresponds to a 0.67 percentage point decline in returns for financials and 0.75 percentage point decline for the broader market. Hence, tighter macroprudential FX regulations reduce the sensitivity of stock returns to exchange rate shocks for both banks and the broader economy, but the effect is almost twice as large for banks (and insignificant for corporates).

Next, since the broad market index is only a rough proxy for corporate stock returns (as this includes banks as well as non-bank financial institutions), column (5) shows results when an artificially-constructed measure of corporate stock returns is used instead of the broad market index. This proxy is calculated by regressing the broad market return index on the financial return index and taking the residual. This should better isolate the impact on corporate returns-but should be interpreted cautiously as this regression could also remove the effects of any omitted variables that affect both corporate and financial stock returns. With this caveat, the estimates support the model's predictions that FX macroprudential regulations reduce corporate sensitivity to exchange rate movements by less than that for banks. More specifically, the coefficient on the interaction term between FX regulation and the exchange rate is insignificant and positive-a sharp contrast to the negative and significant coefficient for the financial index, as well as to the negative and sometimes weakly significant coefficient for the broad index. Since the coefficient estimate is insignificant, we are cautious about interpreting the sign of the effect on corporates-but instead can conclude that this result suggests any effect of macroprudential regulations on the sensitivity of corporates to exchange rate movements is small and insignificant. 47

\footnotetext{
47 It is also possible, however, that these estimates understate the reduction in FX exposure due to the differential impact on small firms. More specifically, smaller firms are more likely to rely on banks for funding, and if FX regulations cause banks to reduce their FX lending to these smaller firms, these firms may be unable to issue debt on international markets. These smaller firms would therefore be forced to reduce their FX borrowing and exposurewhether by shifting to local currency borrowing or not borrowing at all. These effects would not be captured in the empirical analysis as these smaller firms are also less likely to be included as part as the main equity index.
} 
The final four columns of Table 5 further explore this relationship between macroprudential FX regulations and sensitivity to exchange rate movements under two scenarios when the impact of exchange rate movements on stock returns is expected to be larger than average: for emerging markets (which tend to have greater exposure to $\mathrm{FX}$ ) and for larger exchange rate movements. An extensive literature focuses on the greater sensitivity of emerging markets to exchange rate movements (e.g., Eichengreen and Hausmann, 1999; Acharya et al., 2015; Chui et al., 2014 and 2016), so columns (6) and (7) repeat the main results (with the full set of controls) for only the emerging markets in our sample. Other work has suggested that the impact of exchange rate movements on the economy may be non-linear and greater after large movements, especially depreciations (e.g., Kappler et al. 2013)-so columns (8) and (9) report results only for large exchange rate movements, defined as movements in the exchange rate below the 1oth percentile and above the 9oth percentile. In both of these scenarios, the key signs and significance from the base case remain unchangedbut the estimated magnitudes of the coefficients are all larger. For example, and most relevant to this paper's analysis, tighter macroprudential FX regulations correspond to a greater reduction in the exchange rate sensitivity of emerging markets, and to all countries after large exchange rate movements, than occurs for the full sample.

Finally, Appendix Table B3 reports a final set of robustness checks-all of which agree with the main results in Table 5. Columns (1) and (2) use the first lags of all control variables to mitigate endogeneity concerns. Columns (3) and (4) exclude the variables for the stock market turnover ratio and the rule of law, as both were interpolated from annual to quarterly frequency. Next, columns (5) and (6) exclude 2008Q4, which was a period of very sharp exchange rate movements (corresponding to the collapse of Lehman Brothers). We have also repeated the analysis using dollar exchange rates (instead of financial-exposure weighted exchange rates) to calculate exchange rate movements for each country $\left(\Delta\right.$ exrate $\left._{i, t}\right)$.

In each of these sensitivity tests, the key results are unchanged. Macroprudential FX regulation significantly reduces the sensitivity of bank stock returns to exchange rate movements. The sensitivity of stock returns for the broader economy may also be reduced, but this effect is often insignificant and smaller than that for banks.

\section{The Channels Through Which FX Regulations Affect Banks}

The last section has shown that macroprudential FX regulations correspond to a significant reduction in the sensitivity of bank stock returns to exchange rate movements; but 
how does this occur? This section provides some initial evidence, focusing on the key mechanisms suggested in the theoretical model and for which data for our cross-section of countries (particularly emerging markets) is available. Specifically, Section II.C. highlights three channels through which FX regulations could affect banks' lending outcomes:

- The lending rate that banks charge to their customers increases, due to the tax from the regulations.

- The number of firms that borrow from banks declines, because the associated rise in borrowing costs forces low productivity firms to shift from bank funding to investor funding.

- The share of non-performing bank loans falls, because low productivity firms borrow less from banks, thereby reducing banks' shares of low-quality borrowers.

Table 6 reports empirical evidence on these three effects using annual data. ${ }^{48}$ For each test, we report two results: the coefficient from a regression of the variable of interest on changes in FX regulations (as defined above) with country and time fixed effects, and then the same specification with additional time-varying controls for each country's business and financial cycle (captured by real GDP growth and credit growth, respectively).

Columns (1) and (2) report results for the relationship between FX regulations and banks' risk-adjusted lending rate. Both coefficients on the FX measures are positive and significant (at least at the 10\% level), as expected; a tightening of FX regulations makes lending more expensive and increases the lending rate that banks charge to their customers. Next, Columns (3) and (4) report results for the relationship between FX regulations and the number of borrowers from banks. Both coefficients are negative (as expected), but insignificant. 49 Columns (5) and (6) assess the relationship with the share of banks' nonperforming loans. Both coefficients on FX regulations are again negative, as expected, and significant (at least at the 10\% level). This supports the prediction that tighter FX regulations reduce the share of non-performing loans.

All in all, these results provide additional support for the key mechanisms highlighted in the theoretical model on how tighter macroprudential FX regulations affect banks. These also provide additional support for how these regulations could reduce bank sensitivity to currency movements-by reducing the share of loans made to the low productivity firms that

48 See Appendix A for more information on data definitions and sources.

49 When the analysis is repeated with only FX measures targeting bank assets, both coefficients remain negative and become significant (at the $5 \%$ level). 
are more sensitive to currency movements, and therefore reducing banks' share of nonperforming loans. These results are not definitive empirical tests, however, and should simply be interpreted as conditional correlations which provide supporting evidence for the key channels highlighted throughout this paper.

\section{Conclusions}

A growing literature is beginning to document how macroprudential tools can improve financial stability and reduce the amplification of systemic risk. This literature, however, is also beginning to document how these tools often have unintended consequences. One macroprudential tool which is becoming more widely utilized, but has received relatively less attention in academic research, is regulations on FX exposure. This is despite longstanding evidence that foreign currency exposure can generate important economic vulnerabilities.

This paper attempts to address this gap by analyzing the incidence and impact of macroprudential FX regulations. It develops the key concepts in a theoretical model, compiles a dataset with detailed information on these regulations over time, and then uses it to test the predictions of the model. The results show that after an increase in macroprudential FX regulations: (1) banks borrow and lend less in foreign currency (with no change in their borrowing in local currency); (2) firms shift away from bank FX borrowing and increase their FX borrowing from market investors (with no increase in firm and bank non-FX borrowing from investors); (3) banks are less exposed to exchange rate movements; and (4) firms experience some reduction in their exposure to exchange rate movements, but less than for banks. Each of these results supports the main predictions of the model. This combination of results suggests that even if macroprudential FX regulations on banks accomplish their direct goals and significantly reduce bank vulnerability to currency movements, they also generate meaningful leakages and partially "shift the snowbanks" of FX vulnerability to other sectors of the economy.

Although these empirical results are robust to a number of extensions and sensitivity tests, several caveats are important. The underlying data on foreign currency borrowing may miss important aspects of bank and firm FX exposures. For example, the data includes limited information on firm or bank exposure to foreign currency that occurs without crossing borders (such as if a local household makes a bank deposit in foreign currency). The data also does not 
incorporate any transactions or changes in exposure that occur entirely through trading or lending in a third country (as often occurs in financial centers). Moreover, the analysis does not include information on hedging-whether natural or in financial markets-which could reduce an entity's vulnerability to currency movements even if it has large gross FX positions. Many of these data challenges, however, might be expected to bias estimates toward zero, thereby suggesting some of the effects estimated in the paper could actually be larger if better data existed. For example, if firms respond to tighter FX regulations at home by issuing FX debt abroad and selling it to a foreigner (with the entire transaction in London), this leakage would not be captured in our analysis.

Another important caveat is that the analysis in this paper does not provide a full costbenefit calculation of the impact of macroprudential regulations-either in the theoretical model or the empirical analysis. Macroprudential regulations can have much broader costs and benefits than those explored in this paper-such as on the distortions created as firms, banks and individuals find other ways to reduce the impact of the regulations (perhaps by shifting business to other countries with a different regulatory framework). A full test of these various effects is beyond the scope of this paper-but would be a promising avenue for future work (with datasets better targeted to address these questions).

With these caveats, the results in this paper have important implications for the application of macroprudential policy. One key implication is for the debate on capital controls versus macroprudential policy. Countries concerned about excessive borrowing in foreign currency may consider capital controls (especially for bank borrowing in FX, which is particularly volatile and linked to booms and busts ${ }^{5}$ ). Macroprudential regulations on banks, however, appear to be effective in reducing this vulnerability in the financial system without resorting to capital controls-controls which are illegal in some contexts (such as for EU members and in some trade agreements). Although macroprudential bank regulations can also generate leakages (such as an increase in FX debt issuance by corporates), capital controls can also generate costs and unintended consequences-including other ways of "shifting the snowbank" of FX risks to different sectors of the economy. ${ }^{11}$

$5^{\circ}$ See Hoggarth et al. (2016).

${ }^{51}$ For example, Keller (2018) shows that capital controls can cause banks to increase FX lending to domestic firms (in order to better hedge their foreign currency deposits when international hedging becomes more expensive), thereby causing an increase in the foreign currency exposure of domestic companies. For other evidence on the costs and distortions created by capital controls, see Forbes (2007). 
A final set of implications for the application of macroprudential policies is the importance of the regulatory perimeter and implications for aggregate welfare if macroprudential policies partially shift risks from the regulated sector to unregulated sectors. Our results suggest that macroprudential FX regulations can reduce risks in a systemicallyimportant sector of the economy (banks). This needs to be balanced, however, against any increase in risks in other sectors which are in the "shadow" and potentially less well understood than those in the regulated sector..$^{2}$ Are these shadow investors less informed and/or less able to manage exchange rate movements than banks? Do the regulations generate other costs, such as by reducing output due to the less efficient allocation of FX lending by investors which lack the knowledge from banks' screening activities? Even if the overall FX exposure of the economy falls, does this benefit outweigh other costs of the regulation? Just as a fresh snowbank rarely stays white for long, the impact of macroprudential regulation on country resilience can quickly get muddy.

52 Bengui and Bianchi (2014) explore this question in a model of the impact of capital controls, a model which finds that the controls reduce risk on regulated agents but increase risk taking in the "shadow" economy. 


\section{References}

Acharya, V., S. Cecchetti, J. D. Gregorio, S. Kalemli-Ozcan, P. Lane, and U. Panizza (2015). Corporate Debt in Emerging Economies: A Threat to Financial Stability? Report for Committee on International Economics Policy and Reform (CIEPR) and Brookings Institute.

Agénor, P.-R. (2016). Growth and Welfare Effects of Macroprudential Regulation, Centre for Growth and Business Cycle Research Discussion Paper Series 218, Economics, The University of Manchester.

Agénor, P.-R. and L. P. da Silva. (2017). Financial Spillovers, Spillbacks, and the Scope for International Macroprudential Policy Coordination. Unpublished mimeo.

Aguirre, H., and G. Repetto (2017). Capital and Currency-Based Macroprudential Policies: An Evaluation Using Credit Registry Data. BIS Working Papers No. 672.

Ahnert, T., K. Forbes, C. Friedrich, and D. Reinhardt. (2018). "Macroprudential FX Regulations: Shifting the Snowbanks of FX Vulnerability?” MIT-Sloan School of Management Working Paper 5293-18.

Aiyar, S., C. W. Calomiris, and T. Wieladek. (2014). Does Macro-Prudential Regulation Leak? Evidence from a UK Policy Experiment. Journal of Money, Credit and Banking, 46(s1), 181-214.

Akerlof, G. (1970). “The Market for 'Lemons': Quality Uncertainty and the Market Mechanism.” Quarterly Journal of Economics, 84(3), 488-500.

Akinci, O. and J. Olmstead-Rumsey (2015). How Effective are Macroprudential Policies? An Empirical Investigation. International Finance Discussion Paper 1136, Board of Governors of the Federal Reserve System (U.S.).

Auerbach, A. and Y. Gorodnichenko (2013). Measuring the Output Responses to Fiscal Policy. American Economic Journal: Economic Policy 4(2): 1-27.

Avdjiev, S., L. Gambacorta, L. Goldberg, and S. Schiaffi (2016a). The Shifting Drivers of International Capital Flows. Unpublished mimeo.

Avdjiev, S., C. Koch, P. McGuire, and G. von Peter (2016b). International Prudential Policy Spillovers: A Global Perspective. BIS working papers no. 589 (October).

Baele, L. G. Bekaert and K. Inghelbrecht (2010). The Determinants of Stock and Bond Return Comovements. Review of Financial Studies, 23(6), 2374-2428.

Beirne, J. and C. Friedrich (2017). Macroprudential Policies, Capital Flows, and the Structure of the Banking Sector. Journal of International Money and Finance 75, 47-68.

Bekaert, G. and A. Mehl (2017). On the Global Financial Market Integration "Swoosh" and the Trilemma. NBER Working Papers 23124.

Bénétrix, A., L. Philip, and J. Shambaugh (2015). International Currency Exposures, Valuation Effects and the Global Financial Crisis. Journal of International Economics, 96(1), 98-109.

Bengui, J. and J. Bianchi (2014). Capital Flow Management when Capital Controls Leak. Available at: https://www.dropbox.com/s/hbh844zta3vtcbs/ShadowMP latest.pdf.

Benmelech, E. (2012). An Empirical Analysis of the Fed's Term Auction Facility. NBER Working Papers 18304. 
Bernard, A., J. Eaton, B.J. Jensen, and S. Kortum (2003). Plants and Productivity in International Trade. American Economic Review 93(4):1268-90.

Bordo, M. and C. Meissner (2005). The Role of Foreign Currency Debt in Financial Crises: 1880-1913 vs. 1972-1997. NBER Working Papers 11897.

Borio, C., R. McCauley, and P. McGuire (2017). FX Swaps and Forwards: Missing Global Debt? BIS Quarterly Review September 2017.

Brauning, F. and V. Ivashina (2017). Monetary Policy and Global Banking. NBER Working Paper 23316.

Brown, M. and R. De Haas (2012). Foreign Currency Lending in Emerging Europe: Banklevel Evidence, Economic Policy, 27(69), 59-98.

Brown, M., K. Kirschenmann, and S. Ongena (2014). Foreign Currency Loans-Demand or Supply Driven? Journal of Money, Credit and Banking 46(7), 1313-554.

Bruno, V. and H. Shin (2016). Cross-Border Banking and Global Liquidity. Review of Economic Studies 82 (2).

Bruno, V., I. Shim, and H. Shin (2015). Comparative Assessment of Macroprudential Policies. BIS Working Papers 502.

Cerutti, E., R. Correa, E. Fiorentino, and E. Segalla (2017). Changes in Prudential Policy Instruments-A New Cross-Country Database. International Journal of Central Banking 13 (S1), March.

Cerutti, E., S. Claessens, and L. Laeven (2015). The Use and Effectiveness of Macroprudential Policies: New Evidence. IMF Working Papers 15/61.

Cesa-Bianchi, A. Cespedes, L. F. and A. Rebucci (2015) Global Liquidity, House Prices, and the Macroeconomy: Evidence from Advanced and Emerging Economies. IMF Working Papers 15/23.

Chinn, M. D. and H. Ito (2008). A New Measure of Financial Openness. Journal of Comparative Policy Analysis, Volume 10, Issue 3, 309-322. Note that this paper uses the most recent version of the dataset.

Chui, M., I. Fender, and V. Sushko (2014). Risks Related to EME Corporate Balance Sheets: the Role of Leverage and Currency Mismatch. BIS Quarterly Review, 35-47.

Chui, M., E. Kuruc, and P. Turner (2016). A New Dimension to Currency Mismatches in the Emerging Markets: Non-Financial Companies. BIS Working Papers 550.

De Crescenzio, A., M. Golin, and F. Molteni (2017). Have Currency-Based Capital Flow Management Measures Curbed International Banking Flows? OECD Working Papers on International Investment 2017/04.

Dell'Ariccia, G., P. Rabanal, C. Crowe, and D. Igan (2011). Policies for Macrofinancial Stability: Options to Deal with Real Estate Booms. IMF Staff Discussion Notes 11/o2.

Desai, M., C. Foley, and K. Forbes (2008). Financial Constraints and Growth: Multinational and Local Firm Responses to Currency Crises. Review of Financial Studies 21 (6), 28572888.

Du, W. and J. Schreger (2016). Sovereign Risk, Currency Risk, and Corporate Balance Sheets. Unpublished Working Paper. 
Eichengreen, B. and R. Hausmann (1999). Exchange Rates and Financial Fragility. Proceedings - Economic Policy Symposium - Jackson Hole, Federal Reserve Bank of Kansas City, 329-368.

Forbes, K. (2018). Macroprudential Policy after the Crisis: Forging a Thor's Hammer for Financial Stability in Iceland. MIT-Sloan School of Management, mimeo.

Forbes, K. (2007). The Microeconomic Evidence on Capital Controls: No Free Lunch. In Edwards, ed. Capital Controls and Capital Flows in Emerging Economics: Policies, Practices, and Consequences. Chicago: University of Chicago Press, 171-199.

Forbes, K., M. Fratzscher, T. Kostka, and R. Straub (2016). Bubble Thy Neighbour: Portfolio Effects and Externalities from Capital Controls. Journal of International Economics, 99 (C), 85-104.

Forbes, K., M. Fratzscher, and R. Straub (2015). Capital Flow Management Measures: What are They Good For? Journal of International Economics 96 (1, July), S76-S97.

Forbes, K. and F. Warnock (2012). Capital Flow Waves: Surges, Stops, Flight and Retrenchment. Journal of International Economics 88(2, Nov), 235-251.

Furceri, D., P. Loungani and A. Zdzienicka (2016). “The Effects of Monetary Policy Shocks on Inequality. IMF Working Paper WP/16/245.

Ghosh, A., M. Qureshi, and N. Sugawara (2014). Regulating Capital Flows at Both Ends: Does it Work? IMF Working Papers 14/188.

Giordani, P., M. Ruta, H. Weisfeld, and L. Zhu (2014). Capital Flow Deflection. IMF Working Papers 14/145.

Hoggarth, G., C. Jung, and D. Reinhardt (2016). Capital Inflows: the Good, the Bad and the Bubbly. Bank of England Financial Stability Papers 40.

Holmstrom, B. and J. Tirole (1997). Financial Intermediation, Loanable Funds, and the Real Sector. Quarterly Journal of Economics 112(3, Aug), 663-691.

IMF-FSB-BIS (2016). Elements of Effective Macroprudential Policies - Lessons from International Experience. Available at:

https://www.imf.org/external/np/g20/pdf/2016/o83116.pdf.

Kalemli-Ozcan, S., H. Kamil and C. Villegas-Sanchez (2016). What Hinders Investment in the Aftermath of Financial Crises: Insolvent Firms or Illiquid Banks? The Review of Economics and Statistics 98(4): 756-769.

Kang, H., F. Vitek, R. Bhattacharya, P. Jeasakul, S. Munoz, N. Wang, and R. Zandvakil (2017). Macroprudential Policy Spillovers: A Quantitative Analysis. IMF Working Paper $W P / 17 / 170$.

Kappler, M., H. Reisen, M. Schularick, and E. Turkisch (2013). The Macroeconomic Effects of Large Exchange Rate Appreciations. Open Economies Review, 24(3), 471-494.

Kearns, J. and N. Patel (2016). Does the Financial Channel of Exchange Rates Offset the Trade Channel? BIS Quarterly Review, 95-113.

Keeley, M.C. (1990). Deposit Insurance, Risk, and Market Power in Banking, American Economic Review 80(5), 1183-1200.

Keller, L. (2018). Prudential Capital Controls and Risk Misallocation: Bank Lending Channel. Unpublished mimeo. Kellogg School of Management, Northwestern University. 
Kuttner, K. and I. Shim (2013). Can Non-Interest Rate Policies Stabilize Housing Markets? Evidence From a Panel of 57 Economies. BIS Working Papers 433.

Laeven, L. and F. Valencia (2013). Systemic Banking Crises Database. IMF Economic Review 6(2): 225-270.

Lane, P. and J. Shambaugh (2010). Financial Exchange Rates and International Currency Exposures. American Economic Review, 100(1), 518-540.

Melitz, M. (2003). The Impact of Trade on Intra-industry Reallocation and Aggregate Industry Productivity. Econometrica 71:1695-1725.

Mendicino, C., K. Nikolov, J. Suarez, and D. Supera (2015). Welfare Analysis of Implementable Macroprudential Policy Rules: Heterogeneity and Trade-offs. Download: http://www.cemfi.es/ suarez/MNSS_2015.pdf

Nier, E., J. Osinski, L. Jacome, and P. Madrid (2011). Towards Effective Macroprudential Policy Frameworks: An Assessment of Stylized Institutional Models. IMF Working Papers $11 / 250$.

Ostry, J., A. Ghosh, M. Chamon, and M. Qureshi (2012). Tools for Managing Financial Stability Risks from Capital Inflows. Journal of International Economics 88 (2), 407-421.

Pasricha, G., M. Falagiarda, M. Bijsterbosch, and J. Aizenman (2015). Domestic and Multilateral Effects of Capital Controls in Emerging Markets. Bank of Canada Staff Working Papers 15-37.

Ranciere, R., A. Tornell, and A. Vamvakidis (2010). A New Index of Currency Mismatch and Systemic Risk. IMF Working Papers 10/263.

Reinhardt, D. and R. Sowerbutts (2018). Macroprudential Policies: a Granular Database (Revised). Mimeo.

Reinhardt, D. and R. Sowerbutts (2015). Regulatory Arbitrage in Action: Evidence from Banking Flows and Macroprudential Policy. Bank of England Working Papers 546.

Rey, H. (2013). Dilemma not Trilemma: The Global Financial Cycle and Monetary Policy Independence. Proceedings from Jackson Hole Symposium.

Rosenberg C., and M. Tirpák (2009). Determinants of Foreign Currency Borrowing in the New Member States of the EU. Czech Journal of Economics and Finance, 59(3), 216-228.

Shim, I., B. Bogdanova, J. Shek, and A. Subeltye (2013). Database for Policy Actions on Housing Markets. BIS Quarterly Review.

Stiglitz, J., and A. Weiss (1981). Credit Rationing in Markets with Imperfect Information. American Economic Review, 71(3), 393-410.

Vandenbussche, J., U. Vogel, and E. Detragiache (2015). Macroprudential Policies and Housing Prices: a New Database and Empirical Evidence for Central, Eastern, and Southeastern Europe. Journal of Money, Credit and Banking 47 (S1), 343-377.

Wu, J. C. and F. D. Xia (2016). Measuring the Macroeconomic Impact of Monetary Policy at the Zero Lower Bound. Journal of Money, Credit and Banking, 48(3), 253-291.

Zettelmeyer, J., P. Nagy, and S. Jeffrey (2011). Addressing Private Sector Currency Mismatches in Emerging Europe. In M. Kawai and E. Prasad (Eds.), Financial Market Regulation and Reforms in Emerging Markets, 365-406. Washington D.C.: Brookings Institution Press. 


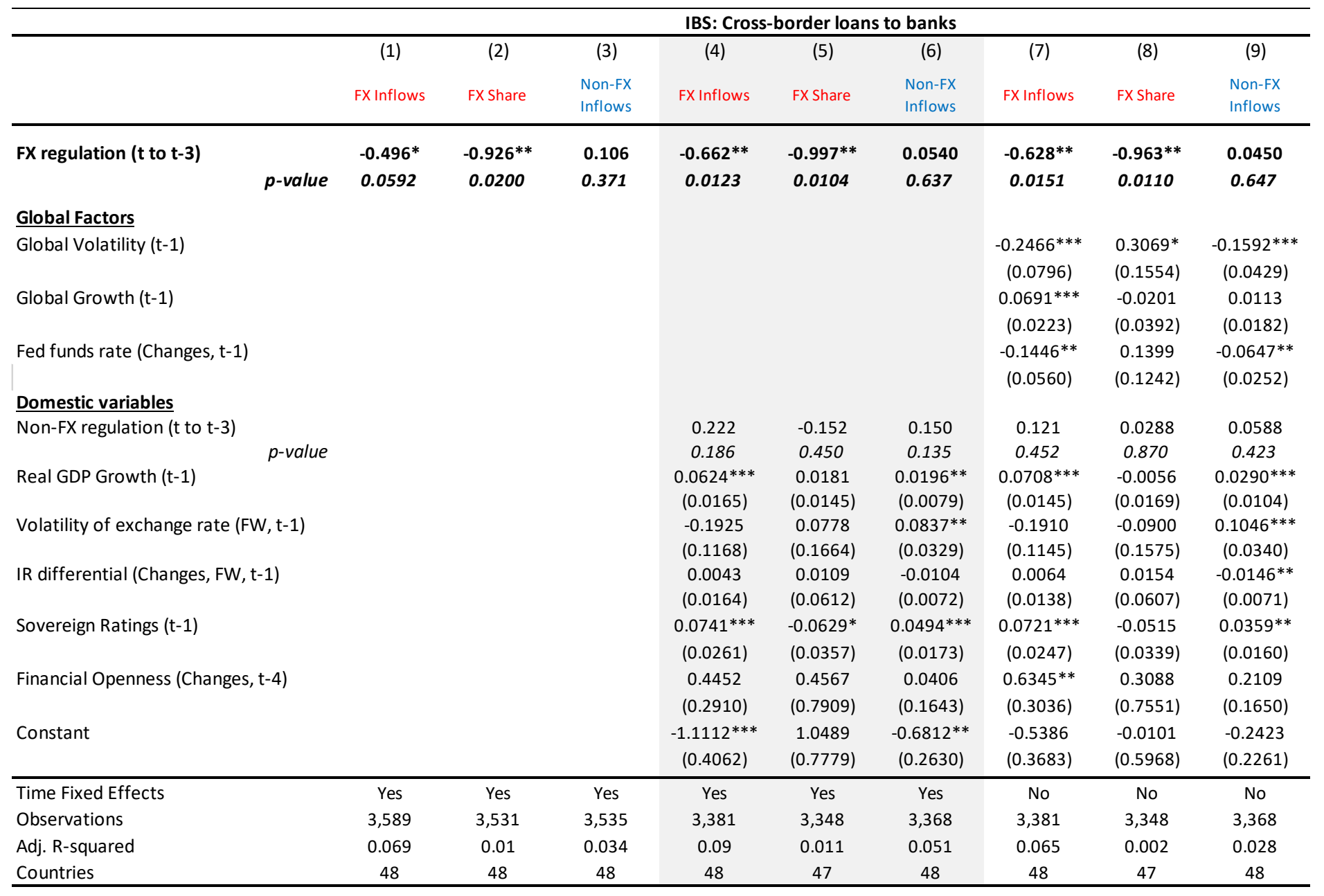

\section{Table 1: Hypothesis \#1 - FX regulations and cross-border debt flows to banks}

The table shows the estimated parameter values from a panel regression of equation (16). All columns include country and time (quarter) fixed effects. The dependent variables are estimated exchange rate-adjusted changes in the stock of cross-border loans from international banks to domestic-resident banks, for loans denominated in foreign or domestic currencies, each expressed as a \% of annual GDP. The columns labelled FX Share use the same data, but express the dependent variable as the change in the share of FX-denominated loans divided by total loans. In columns 7-9, the estimates control for key global factors individually, instead of including a global-time dummy $\left(\delta_{t}\right)$ in equation (16).

Data are from the BIS International Banking Statistics and the split between FX and non-FX components of loans is based on authors' estimates. All data is discussed in Section III, with additional information in Appendix A. FW indicates "financially weighted". The sample period is 1996 Q1 - 2014 Q4. Robust standard errors are clustered at the country level and reported in brackets. ${ }^{* *} / * * / *$ is significant at the $1 \%, 5 \%$, and $10 \%$ levels, respectively. 


\begin{tabular}{|c|c|c|c|c|c|c|c|c|c|}
\hline & \multicolumn{9}{|c|}{ IDS: International debt issuance by corporates } \\
\hline & (1) & (2) & (3) & (4) & (5) & (6) & (7) & (8) & (9) \\
\hline & FX Inflows & FX Share & $\begin{array}{l}\text { Non-FX } \\
\text { Inflows }\end{array}$ & FX Inflows & FX Share & $\begin{array}{l}\text { Non-FX } \\
\text { Inflows }\end{array}$ & FX Inflows & FX Share & $\begin{array}{l}\text { Non-FX } \\
\text { Inflows }\end{array}$ \\
\hline FX regulation ( $t$ to $t-3$ ) & $0.0588^{* *}$ & $0.516^{* *}$ & 0.00848 & $0.0549 * *$ & $0.513 * *$ & 0.00941 & $0.0530 * *$ & $0.464 * *$ & 0.0166 \\
\hline$p$-value & 0.0167 & 0.0280 & 0.796 & 0.0370 & 0.0269 & 0.779 & 0.0336 & 0.0232 & 0.634 \\
\hline \multicolumn{10}{|l|}{ Global Factors } \\
\hline \multirow[t]{2}{*}{ Global Volatility (t-1) } & & & & & & & -0.0033 & -0.0079 & 0.0059 \\
\hline & & & & & & & $(0.0118)$ & $(0.0879)$ & $(0.0042)$ \\
\hline \multirow[t]{2}{*}{ Global Growth (t-1) } & & & & & & & $-0.0063 *$ & -0.0131 & -0.0004 \\
\hline & & & & & & & $(0.0032)$ & $(0.0183)$ & $(0.0011)$ \\
\hline \multirow[t]{2}{*}{ Fed funds rate (Changes, t- 1 ) } & & & & & & & $0.0213^{* *}$ & 0.0892 & 0.0018 \\
\hline & & & & & & & $(0.0081)$ & $(0.0748)$ & $(0.0031)$ \\
\hline \multicolumn{10}{|l|}{ Domestic variables } \\
\hline Non-FX regulation ( $t$ to $t-3$ ) & & & & 0.000220 & 0.0707 & -0.00265 & 0.0123 & 0.0687 & 0.00503 \\
\hline \multirow{3}{*}{ Real GDP Growth (t-1) } & & & & 0.991 & 0.448 & 0.584 & 0.538 & 0.405 & 0.211 \\
\hline & & & & 0.0020 & -0.0004 & -0.0004 & 0.0001 & -0.0061 & -0.0007 \\
\hline & & & & $(0.0013)$ & $(0.0085)$ & $(0.0005)$ & $(0.0012)$ & $(0.0089)$ & $(0.0005)$ \\
\hline \multirow[t]{2}{*}{ Volatility of exchange rate (FW, t-1) } & & & & 0.0134 & 0.0521 & $-0.0082 * *$ & 0.0026 & 0.0524 & $-0.0060^{*}$ \\
\hline & & & & $(0.0107)$ & $(0.0463)$ & (0.0039) & $(0.0102)$ & $(0.0415)$ & $(0.0031)$ \\
\hline \multirow[t]{2}{*}{ IR differential (Changes, FW, t-1) } & & & & $-0.0031^{*}$ & -0.0171 & 0.0005 & $-0.0036^{*}$ & -0.0178 & 0.0001 \\
\hline & & & & $(0.0016)$ & $(0.0170)$ & $(0.0006)$ & $(0.0018)$ & $(0.0211)$ & $(0.0006)$ \\
\hline \multirow[t]{2}{*}{ Sovereign Ratings (t-1) } & & & & 0.0107 & 0.0058 & -0.0012 & $0.0110^{* *}$ & 0.0086 & 0.0012 \\
\hline & & & & $(0.0066)$ & $(0.0148)$ & $(0.0015)$ & $(0.0051)$ & $(0.0191)$ & $(0.0007)$ \\
\hline \multirow[t]{2}{*}{ Financial Openness (Changes, t- 4 ) } & & & & 0.0215 & 0.3201 & -0.0176 & -0.0195 & 0.3150 & $-0.0245^{* *}$ \\
\hline & & & & $(0.0483)$ & $(0.2246)$ & $(0.0112)$ & $(0.0569)$ & $(0.2172)$ & $(0.0112)$ \\
\hline \multirow[t]{2}{*}{ Constant } & & & & -0.1288 & 0.0261 & 0.0207 & -0.0595 & -0.1367 & -0.0100 \\
\hline & & & & $(0.0944)$ & $(0.2706)$ & $(0.0181)$ & $(0.0786)$ & $(0.4124)$ & $(0.0165)$ \\
\hline Time Fixed Effects & Yes & Yes & Yes & Yes & Yes & Yes & No & No & No \\
\hline Observations & 3,344 & 2,804 & 2,736 & 3,147 & 2,728 & 2,613 & 3,147 & 2,728 & 2,613 \\
\hline Adj. R-squared & 0.098 & 0.04 & 0.192 & 0.1 & 0.039 & 0.202 & 0.076 & 0.034 & 0.190 \\
\hline Countries & 44 & 44 & 36 & 44 & 44 & 36 & 44 & 44 & 36 \\
\hline
\end{tabular}

\section{Table 2: Hypothesis \#2: FX regulations and cross-border debt issuance by corporates}

The table shows the estimated parameter values from a panel regression of equation (16). All columns include country and time (quarter) fixed effects. The dependent variables are net issuance of debt securities issued by domestic corporates for debt denominated in foreign or domestic currencies, each expressed as a \% of annual GDP. The columns labelled FX Share use the same data, but express the dependent variables as the change in the share of FX-denominated debt issuance divided by total debt issuance.

Data are from the BIS International Debt Statistics. All data is discussed in Section III, with additional information in Appendix A. FW indicates "financially weighted”. The sample period is 1996 Q1 - 2014 Q4. Robust standard errors are clustered at the country level and reported in brackets. ${ }^{* * *} / * * *$ is significant at the $1 \%, 5 \%$, and $10 \%$ levels, respectively. 


\begin{tabular}{|c|c|c|c|c|c|c|c|c|c|c|c|c|}
\hline & \multicolumn{6}{|c|}{ Liability-side FX regulations } & \multicolumn{6}{|c|}{ Asset-side FX regulations } \\
\hline & \multicolumn{3}{|c|}{ IBS: Cross-border loans to banks } & \multicolumn{3}{|c|}{ IDS: Int. debt issuance by corporates } & \multicolumn{3}{|c|}{ IIBS: Cross-border loans to banks } & \multicolumn{3}{|c|}{ IDS: Int. debt issuance by corporates } \\
\hline & (1) & (2) & (3) & (4) & (5) & (6) & (7) & (8) & (9) & (10) & (11) & (12) \\
\hline & FX Inflows & FXShare & $\begin{array}{l}\text { Non-FX } \\
\text { Inflows }\end{array}$ & FX Inflows & FX Share & $\begin{array}{l}\text { Non-FX } \\
\text { Inflows }\end{array}$ & FX Inflows & FX Share & $\begin{array}{l}\text { Non-FX } \\
\text { Inflows }\end{array}$ & FX Inflows & FX Share & $\begin{array}{l}\text { Non-FX } \\
\text { Inflows }\end{array}$ \\
\hline FX regulation ( $t$ to $t-3$ ) & $-0.487 * *$ & $-1.037^{* *}$ & 0.0569 & $0.0788^{* *}$ & $0.688^{*}$ & -0.0228 & $-1.105^{* *}$ & $-1.075^{*}$ & 0.0168 & 0.0247 & 0.224 & 0.0513 \\
\hline$p$-value & 0.0242 & 0.0186 & 0.608 & 0.0265 & 0.0853 & 0.154 & 0.0300 & 0.0605 & 0.933 & 0.513 & 0.557 & 0.496 \\
\hline \multicolumn{13}{|l|}{ Domestic variables } \\
\hline Non-FX regulation ( $t$ to $t-3$ ) & -0.125 & -0.282 & 0.131 & 0.0287 & $0.160 * *$ & -0.00528 & $0.701 *$ & 0.133 & 0.160 & -0.0409 & 0.0132 & -0.000347 \\
\hline$p$-value & 0.293 & 0.317 & 0.331 & 0.201 & 0.0494 & 0.311 & 0.0728 & 0.685 & 0.188 & 0.201 & 0.950 & 0.967 \\
\hline Real GDP Growth (t-1) & $\begin{array}{c}0.0635^{* * *} \\
(0.0173)\end{array}$ & $\begin{array}{c}0.0183 \\
(0.0145)\end{array}$ & $\begin{array}{c}0.0201 * * \\
(0.0081)\end{array}$ & $\begin{array}{c}0.0019 \\
(0.0013)\end{array}$ & $\begin{array}{l}-0.0008 \\
(0.0084)\end{array}$ & $\begin{array}{l}-0.0004 \\
(0.0005)\end{array}$ & $\begin{array}{c}0.0603^{* * *} \\
(0.0159)\end{array}$ & $\begin{array}{c}0.0150 \\
(0.0142)\end{array}$ & $\begin{array}{c}0.0199 * * \\
(0.0083)\end{array}$ & $\begin{array}{l}0.0023^{*} \\
(0.0014)\end{array}$ & $\begin{array}{c}0.0019 \\
(0.0083)\end{array}$ & $\begin{array}{l}-0.0005 \\
(0.0005)\end{array}$ \\
\hline Volatility of exchange rate (FW, t-1) & $\begin{array}{l}-0.1937 \\
(0.1168)\end{array}$ & $\begin{array}{c}0.0664 \\
(0.1664)\end{array}$ & $\begin{array}{c}0.0848^{* *} \\
(0.0333)\end{array}$ & $\begin{array}{c}0.0134 \\
(0.0105)\end{array}$ & $\begin{array}{c}0.0551 \\
(0.0450)\end{array}$ & $\begin{array}{c}-0.0082^{* *} \\
(0.0039)\end{array}$ & $\begin{array}{l}-0.1838 \\
(0.1160)\end{array}$ & $\begin{array}{c}0.0728 \\
(0.1656)\end{array}$ & $\begin{array}{c}0.0855^{* *} \\
(0.0337)\end{array}$ & $\begin{array}{c}0.0131 \\
(0.0106)\end{array}$ & $\begin{array}{c}0.0455 \\
(0.0467)\end{array}$ & $\begin{array}{c}-0.0087^{* *} \\
(0.0041)\end{array}$ \\
\hline IR differential (Changes, FW, t-1) & $\begin{array}{c}0.0083 \\
(0.0160)\end{array}$ & $\begin{array}{c}0.0159 \\
(0.0618)\end{array}$ & $\begin{array}{l}-0.0104 \\
(0.0072)\end{array}$ & $\begin{array}{c}-0.0033^{*} \\
(0.0017)\end{array}$ & $\begin{array}{l}-0.0183 \\
(0.0172)\end{array}$ & $\begin{array}{c}0.0006 \\
(0.0006)\end{array}$ & $\begin{array}{c}0.0044 \\
(0.0159)\end{array}$ & $\begin{array}{c}0.0071 \\
(0.0643)\end{array}$ & $\begin{array}{l}-0.0090 \\
(0.0074)\end{array}$ & $\begin{array}{c}-0.0029 * \\
(0.0017)\end{array}$ & $\begin{array}{c}-0.0160 \\
(0.0175)\end{array}$ & $\begin{array}{c}0.0006 \\
(0.0006)\end{array}$ \\
\hline Sovereign Ratings (t-1) & $\begin{array}{c}0.0741^{* * *} \\
(0.0260)\end{array}$ & $\begin{array}{c}-0.0651^{*} \\
(0.0357)\end{array}$ & $\begin{array}{c}0.0498^{* * *} \\
(0.0176)\end{array}$ & $\begin{array}{c}0.0108 \\
(0.0067)\end{array}$ & $\begin{array}{c}0.0069 \\
(0.0152)\end{array}$ & $\begin{array}{l}-0.0012 \\
(0.0015)\end{array}$ & $\begin{array}{c}0.0744^{* * *} \\
(0.0272)\end{array}$ & $\begin{array}{c}-0.0600 \\
(0.0359)\end{array}$ & $\begin{array}{c}0.0488^{* * *} \\
(0.0176)\end{array}$ & $\begin{array}{c}0.0108 \\
(0.0066)\end{array}$ & $\begin{array}{c}0.0062 \\
(0.0156)\end{array}$ & $\begin{array}{l}-0.0013 \\
(0.0016)\end{array}$ \\
\hline Financial Openness (Changes, t- 4 ) & $\begin{array}{c}0.4305 \\
(0.2859)\end{array}$ & $\begin{array}{c}0.4403 \\
(0.7895)\end{array}$ & $\begin{array}{c}0.0481 \\
(0.1656)\end{array}$ & $\begin{array}{c}0.0212 \\
(0.0487)\end{array}$ & $\begin{array}{c}0.3303 \\
(0.2261)\end{array}$ & $\begin{array}{l}-0.0165 \\
(0.0115)\end{array}$ & $\begin{array}{c}0.4173 \\
(0.2886)\end{array}$ & $\begin{array}{c}0.4315 \\
(0.7926)\end{array}$ & $\begin{array}{c}0.0400 \\
(0.1631)\end{array}$ & $\begin{array}{c}0.0254 \\
(0.0485)\end{array}$ & $\begin{array}{c}0.3432 \\
(0.2197)\end{array}$ & $\begin{array}{l}-0.0188 \\
(0.0111)\end{array}$ \\
\hline Constant & $\begin{array}{c}-1.1091^{* * *} \\
(0.4071)\end{array}$ & $\begin{array}{c}1.0913 \\
(0.7791)\end{array}$ & $\begin{array}{c}-0.6896^{* *} \\
(0.2682)\end{array}$ & $\begin{array}{l}-0.1292 \\
(0.0948)\end{array}$ & $\begin{array}{c}0.0071 \\
(0.2731)\end{array}$ & $\begin{array}{c}0.0201 \\
(0.0178)\end{array}$ & $\begin{array}{c}-1.1182^{* *} \\
(0.4224)\end{array}$ & $\begin{array}{c}1.0385 \\
(0.7759)\end{array}$ & $\begin{array}{c}-0.6761^{* *} \\
(0.2689)\end{array}$ & $\begin{array}{l}-0.1307 \\
(0.0933)\end{array}$ & $\begin{array}{c}0.0245 \\
(0.2843)\end{array}$ & $\begin{array}{c}0.0234 \\
(0.0190)\end{array}$ \\
\hline Time Fixed Effects & Yes & Yes & Yes & Yes & Yes & Yes & Yes & Yes & Yes & Yes & Yes & Yes \\
\hline Observations & 3,381 & 3,348 & 3,368 & 3,147 & 2,728 & 2,613 & 3,381 & 3,348 & 3,368 & 3,147 & 2,728 & 2,613 \\
\hline Adj. R-squared & 0.089 & 0.011 & 0.049 & 0.101 & 0.039 & 0.202 & 0.092 & 0.01 & 0.049 & 0.1 & 0.039 & 0.203 \\
\hline Countries & 48 & 47 & 48 & 44 & 44 & 36 & 48 & 47 & 48 & 44 & 44 & 36 \\
\hline
\end{tabular}

\section{Table 3: Liability-side vs asset-side macroprudential FX regulations and cross-border bank and debt flows}

The table presents the estimated parameter values from panel regressions. All columns include country and quarter fixed effects. See footnote to Tables 1 and 2 for variable definitions. Data are from the BIS International Banking and Debt Statistics. The split in FX and non-FX components of loans is based on authors' estimates. The sample period is 1996 Q1 - 2014 Q4. Robust standard errors, clustered at the country level, are reported in brackets. ${ }^{* * * * *} /{ }^{*}$ is significant at the $1 \%, 5 \%$, and $10 \%$ level. 
Table 4a: First-stage regressions predicting changes in FX regulations

\begin{tabular}{|c|c|c|c|c|c|c|}
\hline & \multicolumn{6}{|c|}{ FX Regulations } \\
\hline & (1) & $(2)$ & (3) & (4) & (5) & (6) \\
\hline & Model 1 & Model 2 & Model 3 & Model 4 & Model 5 & Model 6 \\
\hline \multirow[t]{2}{*}{ Real GDP Growth (t-1) } & 0.0010 & -0.0018 & 0.0005 & -0.0006 & 0.0004 & 0.0009 \\
\hline & $(0.0013)$ & $(0.0016)$ & $(0.0013)$ & $(0.0014)$ & $(0.0014)$ & $(0.0014)$ \\
\hline \multirow[t]{2}{*}{ Exchange Rate Appreciation (FW, t-1) } & $0.0015^{* *}$ & $0.0012^{* *}$ & $0.0016^{* *}$ & $0.0013^{*}$ & $0.0014^{* *}$ & $0.0014 * *$ \\
\hline & $(0.0006)$ & $(0.0006)$ & $(0.0006)$ & $(0.0007)$ & $(0.0006)$ & $(0.0006)$ \\
\hline \multirow[t]{2}{*}{ Financial Openness (Changes, t-4) } & $0.0580^{*}$ & 0.0449 & $0.0572 *$ & 0.0307 & $0.0572 *$ & $0.0573^{*}$ \\
\hline & (0.0309) & $(0.0292)$ & $(0.0310)$ & $(0.0346)$ & $(0.0307)$ & $(0.0320)$ \\
\hline \multirow[t]{2}{*}{ Non-FX regulation $(t-1)$} & 0.0068 & -0.0017 & 0.0062 & 0.0096 & 0.0009 & -0.0006 \\
\hline & $(0.0126)$ & $(0.0102)$ & $(0.0127)$ & $(0.0121)$ & $(0.0105)$ & $(0.0112)$ \\
\hline \multirow[t]{2}{*}{ One year ahead WEO GDP growth forecast } & & $0.0127 * *$ & & & & \\
\hline & & $(0.0062)$ & & & & \\
\hline \multirow[t]{2}{*}{ Domestic Credit Growth (t-1, yoy) } & & & 0.0005 & & & \\
\hline & & & $(0.0006)$ & & & \\
\hline \multirow[t]{2}{*}{ Real Houseprice Growth (t-1, yoy) } & & & & 0.0008 & & \\
\hline & & & & $(0.0007)$ & & \\
\hline \multirow[t]{2}{*}{ Cross-border FX loans to banks (sum t-1 to t-2) } & & & & & 0.0003 & \\
\hline & & & & & $(0.0007)$ & \\
\hline \multirow[t]{2}{*}{ International Debt Issuance by Corporates (sum t-1 to t-2) } & & & & & & $0.0156^{*}$ \\
\hline & & & & & & $(0.0092)$ \\
\hline \multirow[t]{2}{*}{ Constant } & 0.0041 & $-0.0312^{*}$ & 0.0051 & 0.0023 & 0.0058 & 0.0036 \\
\hline & $(0.0057)$ & $(0.0186)$ & $(0.0061)$ & $(0.0081)$ & $(0.0062)$ & $(0.0061)$ \\
\hline Time and Country Fixed Effects & Yes & Yes & Yes & Yes & Yes & Yes \\
\hline Observations & 3,381 & 3,372 & 3,214 & 2,665 & 3,366 & 3,130 \\
\hline Adj. R-squared & 0.0175 & 0.0221 & 0.0168 & 0.0279 & 0.0172 & 0.0186 \\
\hline Countries & 48 & 48 & 48 & 43 & 48 & 44 \\
\hline
\end{tabular}

Table 4b: Key coefficients from $2^{\text {nd }}$-stage regressions of baseline model

\begin{tabular}{|c|c|c|c|c|c|}
\hline & & \multicolumn{2}{|c|}{ IBS: Cross-border loans to banks } & \multicolumn{2}{|c|}{ IDS: Int. debt issuance by corporates } \\
\hline & & (1) & (2) & (3) & (4) \\
\hline & & FXInflows & FX Share & FXInflows & FX Share \\
\hline \multicolumn{6}{|c|}{ FX regulation ( $t$ to $t-3$ ) } \\
\hline \multirow[t]{2}{*}{ Model 1} & & $-0.710^{* *}$ & $-0.935 * *$ & $0.0598 * *$ & $0.523 * *$ \\
\hline & $p$-value & 0.0127 & 0.0241 & 0.0295 & 0.0354 \\
\hline \multirow[t]{2}{*}{ Model 2} & & $-0.630 * *$ & $-1.008 * *$ & $0.0598^{* *}$ & $0.524 * *$ \\
\hline & $p$-value & 0.0161 & 0.0175 & 0.0313 & 0.0358 \\
\hline \multirow[t]{2}{*}{ Model 3} & & $-0.718^{* *}$ & $-0.915^{* *}$ & $0.0584 * *$ & $0.547 * *$ \\
\hline & $p$-value & 0.0102 & 0.0205 & 0.0481 & 0.0314 \\
\hline \multirow[t]{2}{*}{ Model 4} & & $-0.936 * * *$ & -0.692 & $0.0576^{*}$ & $0.592^{* *}$ \\
\hline & $p$-value & 0.00225 & 0.137 & 0.0774 & 0.0150 \\
\hline \multirow[t]{2}{*}{ Model 5} & & $-0.616^{* *}$ & $-1.030 * *$ & $0.0598 * *$ & $0.523 * *$ \\
\hline & $p$-value & 0.0187 & 0.0152 & 0.0296 & 0.0351 \\
\hline \multirow[t]{2}{*}{ Model 6} & & $-0.569 * *$ & $-0.989 * *$ & $0.0597^{* *}$ & $0.523 * *$ \\
\hline & $p$-value & 0.0417 & 0.0244 & 0.0296 & 0.0355 \\
\hline
\end{tabular}

\section{Table 4: More exogenous measures of macroprudential FX regulations}

Table 4a shows results of first-stage regressions of changes in macroprudential FX regulations on a range of explanatory variables. Table $4 \mathrm{~b}$ then uses the residuals of these six different first-stage regressions as a more exogenous measure of macroprudential FX regulations in equation (12), replicating column 4 of Tables 1 and 2. The "Model" number listed in each row in Table 4B corresponds to the same numbered column in Table 4a. See notes to Tables 1 and 2 for more details, and Appendix A for variable definitions. Robust standard errors, clustered at the country level, are reported in brackets. ${ }^{* *} /{ }^{* *} /{ }^{*}$ is significant at the $1 \%, 5 \%$, and $10 \%$ level. 


\begin{tabular}{|c|c|c|c|c|c|c|c|c|c|}
\hline \multirow[b]{2}{*}{ Stock Returns } & \multicolumn{2}{|c|}{ Limited Controls } & \multicolumn{3}{|c|}{ Base } & \multicolumn{2}{|c|}{ Emerging Markets } & \multicolumn{2}{|c|}{ Large ER Moves } \\
\hline & $(1)$ & $(2)$ & (3) & (4) & (5) & (6) & (7) & (8) & (9) \\
\hline By & Fin. & Broad & Fin. & Broad & Corp. & Fin. & Broad & Fin. & Broad \\
\hline \multirow[t]{2}{*}{ Cum. FX Regulation (t to $t-3$ ) } & -0.555 & 0.470 & -1.504 & -0.629 & 0.205 & $-2.437^{*}$ & -1.116 & $-5.335^{* *}$ & -3.310 \\
\hline & $(1.538)$ & $(1.230)$ & $(1.298)$ & $(1.467)$ & $(0.981)$ & $(1.190)$ & $(1.482)$ & $(2.275)$ & $(2.583)$ \\
\hline \multirow[t]{2}{*}{ Ex. Rate Appreciation (FW) (t) } & $1.956 * * *$ & $1.648 * * *$ & $1.459 * * *$ & $1.184 * * *$ & $0.179 *$ & $1.810 * * *$ & $1.436 * * *$ & $1.635 * * *$ & $1.315^{* * *}$ \\
\hline & $(0.214)$ & $(0.154)$ & $(0.224)$ & $(0.162)$ & $(0.101)$ & $(0.238)$ & $(0.165)$ & $(0.229)$ & $(0.196)$ \\
\hline \multirow[t]{2}{*}{ FX Regulation X Ex. Rate Apprec. (FW) (t) } & $-0.689 * *$ & -0.379 & $-0.781 * * *$ & $-0.432 *$ & 0.023 & $-0.939 * * *$ & $-0.568 * *$ & $-1.093^{* *}$ & -0.705 \\
\hline & $(0.310)$ & $(0.265)$ & $(0.276)$ & $(0.240)$ & $(0.171)$ & $(0.275)$ & $(0.225)$ & $(0.415)$ & $(0.439)$ \\
\hline \multirow{2}{*}{ Industry Production Growth (t) } & & & $0.086^{*}$ & 0.058 & 0.006 & 0.107 & $0.152 * *$ & 0.047 & 0.067 \\
\hline & & & $(0.045)$ & $(0.044)$ & $(0.028)$ & $(0.075)$ & $(0.059)$ & $(0.073)$ & $(0.091)$ \\
\hline \multirow[t]{2}{*}{ Inflation $(t)$} & & & -0.144 & -0.311 & -0.267 & -0.279 & -0.379 & 0.368 & -0.331 \\
\hline & & & $(0.420)$ & $(0.308)$ & $(0.198)$ & $(0.517)$ & $(0.386)$ & $(0.780)$ & $(0.710)$ \\
\hline \multirow[t]{2}{*}{ Short-Term Interest Rate (t) } & & & $-0.278 *$ & $-0.419 * *$ & $-0.218^{*}$ & -0.202 & -0.305 & -0.239 & -0.455 \\
\hline & & & $(0.144)$ & $(0.187)$ & $(0.111)$ & $(0.142)$ & $(0.211)$ & $(0.285)$ & $(0.296)$ \\
\hline \multirow[t]{2}{*}{ Stock Market Turnover Ratio (t) } & & & 0.016 & $0.048 * * *$ & $0.036 * * *$ & 0.016 & 0.030 & $0.067 *$ & $0.078 * * *$ \\
\hline & & & $(0.021)$ & $(0.017)$ & $(0.010)$ & $(0.036)$ & $(0.028)$ & $(0.034)$ & $(0.025)$ \\
\hline \multirow[t]{2}{*}{ Rule of Law (t) } & & & -4.225 & -1.657 & 1.154 & 0.855 & -3.267 & 4.788 & -5.756 \\
\hline & & & (3.229) & $(3.375)$ & $(2.433)$ & (3.707) & (4.528) & (9.649) & $(8.786)$ \\
\hline \multirow[t]{2}{*}{ Global Volatility (t) } & & & $-10.126^{* * *}$ & $-9.859 * * *$ & $-3.374 * * *$ & $-7.824 * * *$ & $-7.681 * * *$ & $-8.854 * * *$ & $-9.089 * * *$ \\
\hline & & & (0.899) & $(0.780)$ & $(0.405)$ & $(0.822)$ & $(0.714)$ & $(1.572)$ & $(1.682)$ \\
\hline Country Fixed Effects & Yes & Yes & Yes & Yes & Yes & Yes & Yes & Yes & Yes \\
\hline Observations & 1,204 & 1,204 & 1,093 & 1,093 & 1,093 & 594 & 594 & 252 & 252 \\
\hline R-squared & 0.18 & 0.17 & 0.34 & 0.39 & 0.16 & 0.38 & 0.39 & 0.52 & 0.56 \\
\hline Number of Countries & 24 & 24 & 23 & 23 & 23 & 13 & 13 & 22 & 22 \\
\hline
\end{tabular}

\section{Table 5: Market vulnerability to currency movements}

The table shows the estimated parameter values from a panel regression of equation (17). All columns include country fixed effects. The dependent variables are stock returns of financials ("Fin."; which is primarily banks), the broad market ("Broad"; which includes banks, non-bank financials, and corporates) and corporates ("Corp"; which is an estimate of corporate returns). All columns control for the cumulated FX regulation measure (summed over the current and the last three quarters), the financially weighted exchange rate (defined as an appreciation of the domestic currency) and their interaction term. Column (5) uses a proxy for corporate stock returns, estimated as the residual of a regression of the broad return index on the financial index. Columns (6) and (7) restrict the sample to emerging markets. Columns (8) and (9) are based on the full sample, but include only large exchange rate movements (i.e., values below the $10^{\text {th }}$ and above the $90^{\text {th }}$ percentile in the distribution of exchange rate movements). The specifications and data are discussed in Sections III and VI. Additional information is provided in Appendix A. The sample period is 2000 Q1 - 2014 Q4. Robust standard errors are clustered at the country level and reported in brackets. ${ }^{* * *} / * * *$ is significant at the $1 \%, 5 \%$, and $10 \%$ levels, respectively. The larger value of each coefficient pair in absolute terms is marked in bold. 


\begin{tabular}{lcccccc}
\hline & $(1)$ & $(2)$ & $(3)$ & $(4)$ & $\begin{array}{c}(5) \\
\text { Share of NP Loans }\end{array}$ \\
Dependent Variable & & & & & & $(6)$ \\
& Risk-Adj. Lending Rate & Number of Borrowers & & & & \\
Cum. FX Regulation (t to t-3) & $1.943^{*}$ & $2.302^{* *}$ & -23.949 & -22.454 & $-1.078^{* *}$ & $-0.583^{*}$ \\
& $(1.128)$ & $(1.095)$ & $(18.741)$ & $(18.710)$ & $(0.401)$ & $(0.339)$ \\
Real GDP Growth (t-1) & & -0.118 & & -0.313 & $-0.419^{* * *}$ \\
& & $(0.169)$ & & $(2.321)$ & $(0.120)$ \\
Credit Growth (t-1) & & 0.034 & & 0.685 & $-0.088^{* *}$ \\
& & $(0.036)$ & & $(0.948)$ & $(0.037)$ \\
\hline \hline Country Fixed Effects & Yes & Yes & Yes & Yes & Yes & Yes \\
Time Fixed Effects & Yes & Yes & Yes & Yes & Yes & Yes \\
Observations & 344 & 304 & 217 & 215 & 333 & 324 \\
R-squared & 0.79 & 0.85 & 0.96 & 0.97 & 0.77 & 0.81 \\
Countries & 26 & 25 & 25 & 25 & 43 & 43 \\
\hline
\end{tabular}

\section{Table 6: Additional effects of FX regulations on banks}

The table shows the estimated parameter values from panel regressions of three banking sector variables on changes in FX regulations with country and time fixed effects, and then the same specification with additional time-varying controls for each country's business and financial cycle (captured by real GDP growth and credit growth, respectively). The data frequency is annual. The three banking sector variables are "Risk-Adj. Lending Rate" = Risk premium on lending (lending rate minus risk free treasury bill rate, \%); "Number of Borrowers" = Borrowers from commercial banks (per 1,ooo adults); "Share of NP Loans" = Bank non-performing loans to total gross loans (\%). All dependent variables are obtained from the World Bank's World Development Indicators Database and winsorized at the 2.5 percent level Cum. FX Regulation corresponds to the cumulated FX regulation measure (summed over the current and the last three quarters) used in the previous table. Robust standard errors are clustered at the country level and reported in brackets. ${ }^{* * *} /{ }^{* *} /{ }^{*}$ is significant at the $1 \%, 5 \%$, and $10 \%$ levels, respectively. 


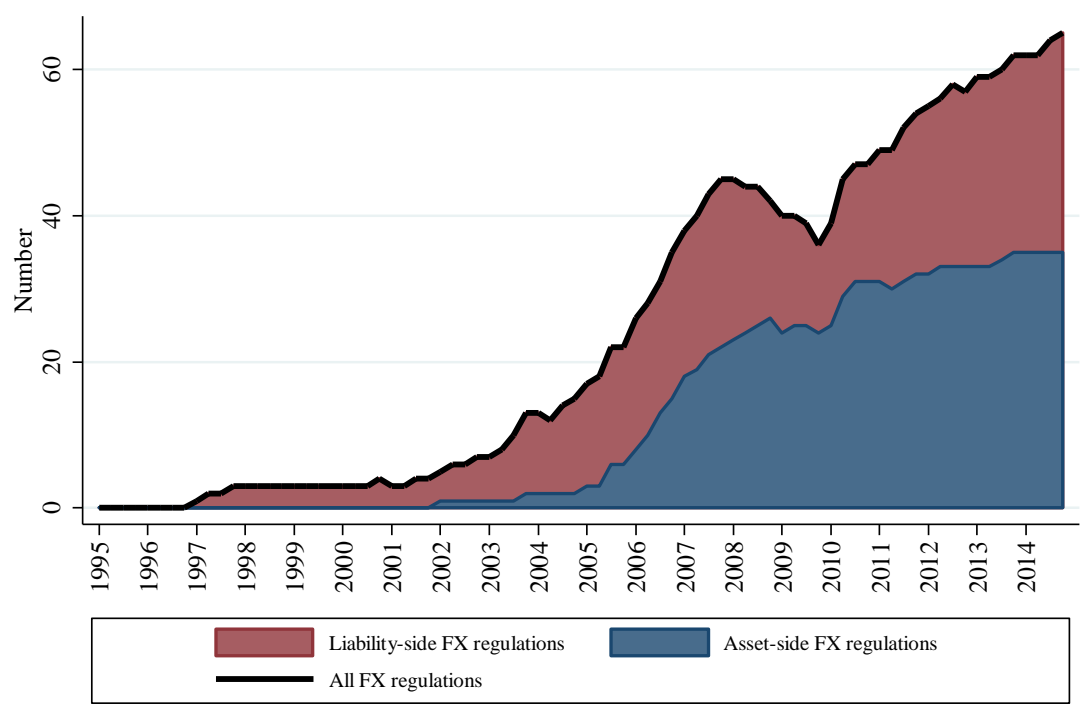

Figure 1: Cumulated changes in macroprudential FX regulations. This figure shows the aggregate number of changes in macroprudential FX regulations in the sample (described in Section III), where changes include both loosening and tightening. The shading divides these actions into those affecting bank assets (in blue) versus those on bank liabilities (in red).

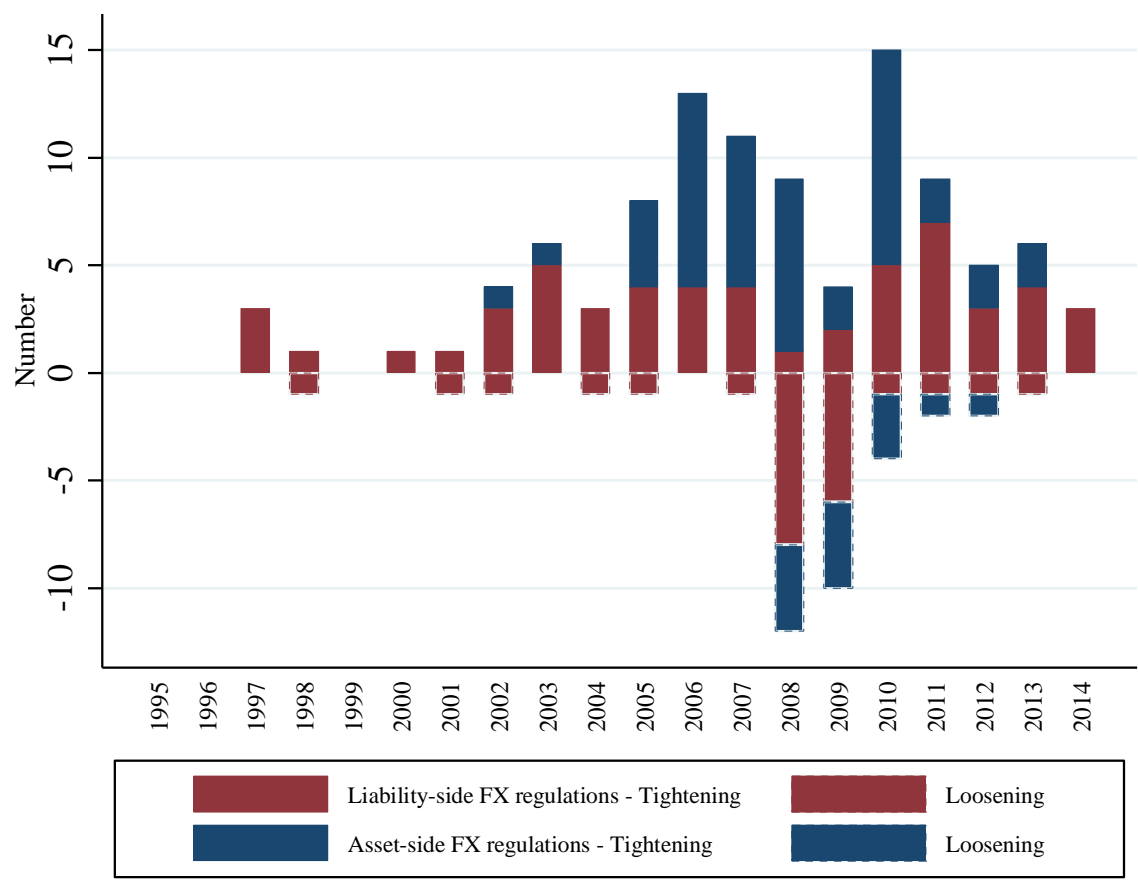

Figure 2: Tightening and loosening of macroprudential FX regulations by category over time. This figure shows the tightening (positive) and loosening (negative) of macroprudential FX measures from our dataset. The shading divides the actions into those affecting bank assets (in blue) and those on bank liabilities (in red). 


\section{Figure 3a}
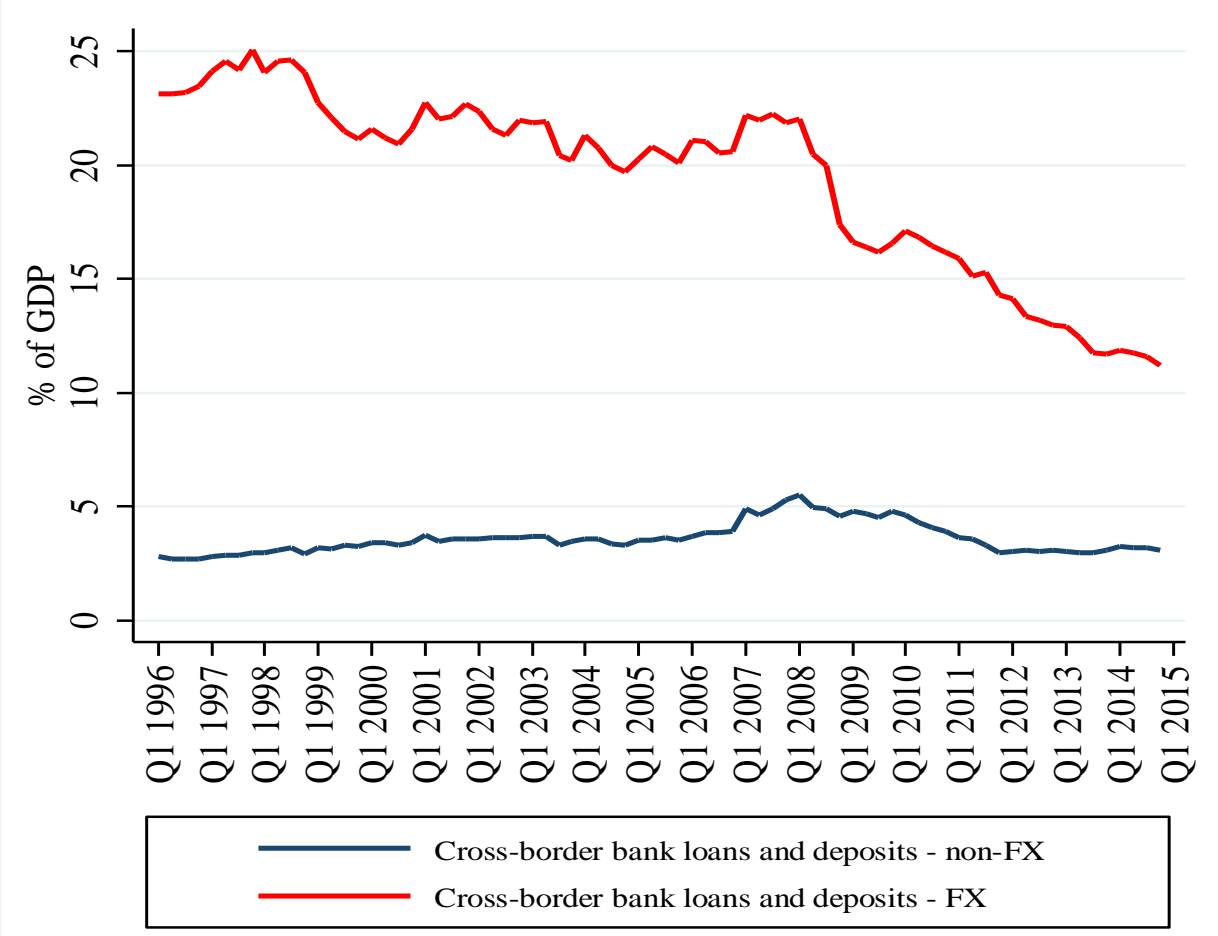

Figure 3b

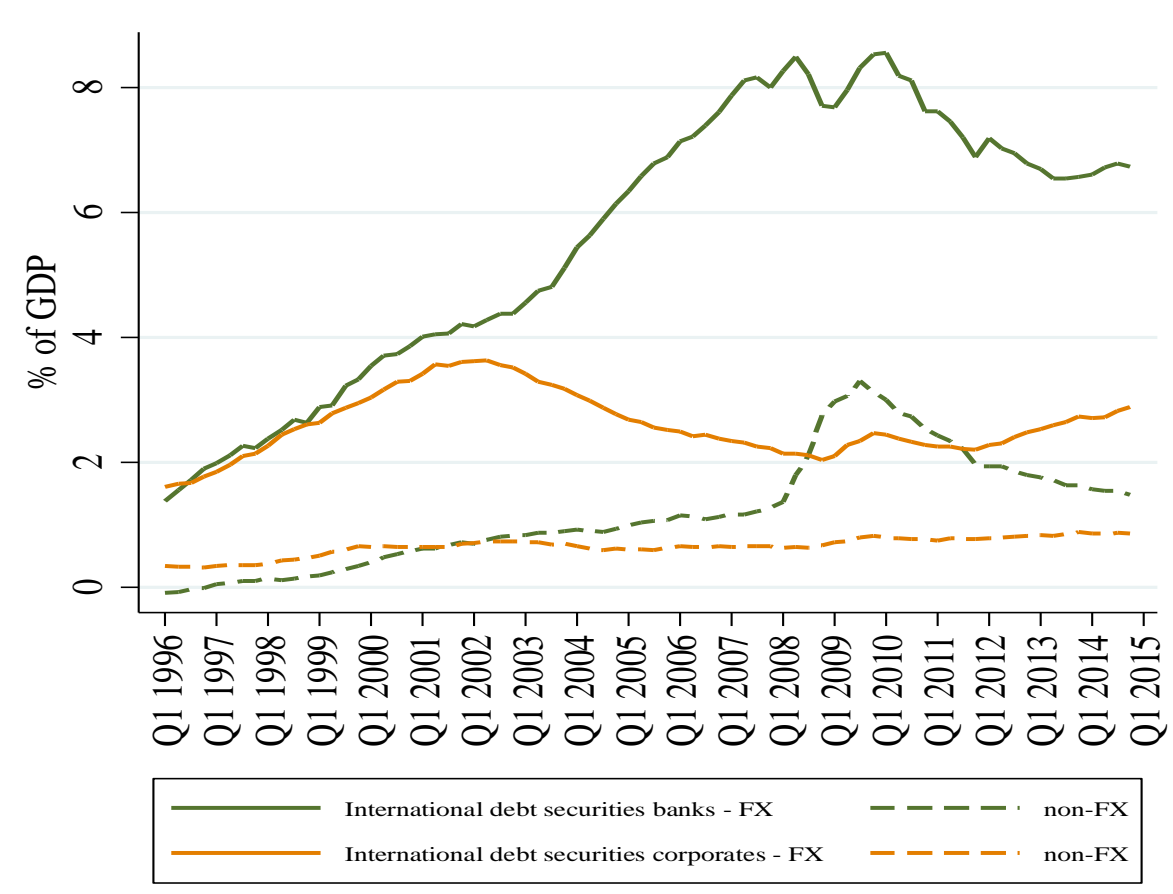

Figures 3a and 3b: Cross-border bank borrowing and international debt issuance over time. Figure 3a shows the evolution of cross-border loans to banks, broken into loans in FX and non-FX. Figure $3 \mathrm{~b}$ shows international debt issuance over the same period, also broken down into FX and non-FX borrowing, and further distinguished by borrowing by banks and corporates. All numbers are scaled by GDP 


\section{Appendix A: Data Sources, Definitions, and Summary Statistics}

We use two databases on international capital flows in order to measure debt and bank capital flows into FX and non-FX denominated flows: the BIS International Banking Statistics (IBS) data for cross-border bank loans provided by international banks 53 and the BIS International Debt Statistics (IDS) for the issuance of debt securities of domestic banks and corporates on international debt markets (and hence potentially bought by all types of creditors, i.e., banks and non-banks).

For the IBS (international loan) data, the currency denomination of cross-border bank loan liabilities needs to be estimated using information on cross-border bank loan assets from all BISreporting countries to a large set of countries. This is because only a fraction of the countries in our sample are BIS reporters and even for BIS reporters we only have information on the FX-loan liabilities of the banking system and no information on the balance sheet of non-banks. Consequently, we match information on the currency denomination of loans by international banks with the currency in use in the receiving country to determine whether a specific currencylending pair can be classified as FX or non-FX from the perspective of the receiving country.

For the IDS (international debt) data, data on residency basis include information on the currency denomination of debt issuance. The data refer to debt securities issued by domestic headquartered entities on international markets. This is a key component of the portfolio debt category in the balance of payments.

Additional information on control variables is listed in Appendix Table A1.

\section{Appendix Table A1: Data Sources for the Empirical Analysis}

\begin{tabular}{|l|l|l|}
\hline Variable & Description & Source \\
\hline $\begin{array}{l}\text { Domestic Credit } \\
\text { Growth }\end{array}$ & $\begin{array}{l}\text { Quarterly growth in credit by domestic banks to private non- } \\
\text { financial sector to GDP (PBM770A, \%) taken from the BIS or if not } \\
\text { available quarterly growth in claims by other depository } \\
\text { corporations on private sector (scaled by GDP, \%) from IMF IFS. }\end{array}$ & $\begin{array}{l}\text { BIS and } \\
\text { International } \\
\text { Financial } \\
\text { Statistics } \\
\text { (IFS), IMF }\end{array}$ \\
\hline $\begin{array}{l}\text { Exchange rate } \\
\text { appreciation } \\
\text { (FW) }\end{array}$ & $\begin{array}{l}\text { Financially-weighted exchange rate appreciation, defined as } \\
=\text { mean }\left(\sum w_{n, t}^{F} \cdot \Delta e r_{n, t}\right), \text { where } \Delta e r_{n, t} \text { is the log change in the spot } \\
\text { exchange rate in quarter } t \text { vis-à-vis country } n \text { based on weekly data; } \\
w_{n, t}^{F} \text { is the (annual) financial weight of foreign }(F) \text { country } n \text { in } \\
\text { quarter } t . n \text { captures the major currencies/currency areas: USD, } \\
\text { GBP, EUR, YEN, CHF. Financial weights are based on all foreign } \\
\text { assets and liabilities (to capture the financial links for the entire } \\
\text { economy), taken from Bénétrix } \text { et al. } \text { (2015), and are extrapolated } \\
\text { for 2013/2014 based on 2012 values. An increase is an appreciation. } \\
\text { (2015) }\end{array}$ & \\
\hline $\begin{array}{l}\text { Exchange rate } \\
\text { volatility (FW) }\end{array}$ & $\begin{array}{l}\text { Financially-weighted exchange rate volatility, defined as } \\
=s t d . d e v\left(\sum w_{n, t}^{F} \cdot \Delta e r_{n, t}\right), \text { where } \Delta e r_{n, t} \text { is the log change in the spot } \\
\text { exchange rate in quarter } t \text { vis-à-vis country } n \text { based on weekly data; } \\
w_{n, t}^{F} \text { is the (annual) financial weight of foreign }(F) \text { country } n \text { in } \\
\text { quarter } t \text {. The standard deviation of the measure is calculated on a }\end{array}$ & $\begin{array}{l}\text { Data Stream; } \\
\text { (2015) }\end{array}$ \\
\hline
\end{tabular}

53 The IBS data contain only a long enough time series for loans to banks and non-banks respectively. They also include data for disaggregating loans to non-banks into loans to non-bank financials, households and corporates, but this time series is too short for our empirical analysis (starting in 2014 Q1). 


\begin{tabular}{|c|c|c|}
\hline & $\begin{array}{l}\text { quarterly level. } n \text { captures the major currencies/currency areas: } \\
\text { USD, GBP, EUR, YEN, CHF. Financial weights are based on foreign } \\
\text { debt liabilities, taken from Bénétrix et al. (2015), and are } \\
\text { extrapolated for } 2013 / 2014 \text { based on } 2012 \text { values. }\end{array}$ & \\
\hline $\begin{array}{l}\text { Fed funds } \\
\text { rate/Shadow rate } \\
\text { (Changes) }\end{array}$ & $\begin{array}{l}\text { Quarterly change in the effective fed funds rate prior to Q4 } 2008 \\
\text { and Wu-Xia estimates of the shadow federal funds rate from Q1 } \\
\text { 2009. }\end{array}$ & $\begin{array}{l}\text { Wu and Xia } \\
(2016)\end{array}$ \\
\hline $\begin{array}{l}\text { Financial } \\
\text { Openness } \\
\text { (Changes) }\end{array}$ & $\begin{array}{l}\text { The annual index of capital account openness (KAOPEN) from } \\
\text { Chinn and Ito (2008). The index runs from o to 1, where higher } \\
\text { values imply fewer restrictions on the capital account or fewer } \\
\text { financial restrictions on the current account. }\end{array}$ & $\begin{array}{l}\text { Chinn and Ito } \\
\text { (2008, } \\
\text { extended to } \\
\text { 2013) }\end{array}$ \\
\hline $\begin{array}{l}\text { FX Regulation } \\
(\text { fxm })\end{array}$ & $\begin{array}{l}\text { Equal to }+1 \text { for any new or tightening of macroprudential FX } \\
\text { regulations, and }-1 \text { for any removal or reduction in these measures. } \\
\text { See Appendix A of Ahnert et al. (2018) for details. Calculated on a } \\
\text { quarterly basis for the analysis in Section IV, with the } \\
\text { contemporaneous value and three lags included separately in } \\
\text { estimates of equation (14). In Section V, the FX measure is } \\
\text { calculated as the cumulated value over the current and previous } \\
\text { three quarters (still only allowed to equal }-1,0 \text {, or }+1 \text { ) in order to } \\
\text { estimate the interaction term in equation (15). }\end{array}$ & $\begin{array}{l}\text { Calculated. } \\
\text { See Appendix } \\
\text { A of Ahnert et } \\
\text { al. (2018) for } \\
\text { more } \\
\text { information }\end{array}$ \\
\hline Global Growth & Real Quarterly GDP Growth (\%) & IFS, IMF \\
\hline Global Volatility & $\begin{array}{l}\text { Volatility of MSCI World Index. Realized volatility calculated as } \\
\text { square root of the average of the sum of squared log daily returns. } \\
\text { To convert to an annualized value, this is multiplied by the square } \\
\text { root of } 252 \text { divided by the number of trading days in a given month. }\end{array}$ & Data Stream \\
\hline $\begin{array}{l}\text { GDP growth } \\
\text { forecast (one year } \\
\text { ahead) }\end{array}$ & The one-year ahead forecast of real GDP growth. & $\begin{array}{l}\text { World } \\
\text { Economic } \\
\text { Outlook, IMF }\end{array}$ \\
\hline $\begin{array}{l}\text { Industry } \\
\text { Production } \\
\text { Growth }\end{array}$ & $\begin{array}{l}\text { Quarter-on-quarter growth rates of an index of industry production } \\
\text { in each country. Growth rates have been computed based on } \\
\text { changes in the natural logarithm. }\end{array}$ & $\begin{array}{l}\text { Haver } \\
\text { Analytics }\end{array}$ \\
\hline Inflation & $\begin{array}{l}\text { Quarter-on-quarter growth rates of the consumer price index. } \\
\text { Growth rates computed based on changes in the natural logarithm. }\end{array}$ & $\begin{array}{l}\text { Haver } \\
\text { Analytics. }\end{array}$ \\
\hline $\begin{array}{l}\text { IR differential } \\
\text { (Changes, FW) }\end{array}$ & $\begin{array}{l}\text { Financially-weighted interest differential, defined as } \\
=\Delta i_{t}^{D}-\sum w_{n, t}^{F} \cdot \Delta i_{n, t}^{F} \text {, where } \Delta i_{t}^{D} \text { is the nominal money market rate in } \\
\text { quarter } \mathrm{t} ; w_{n, t}^{F} \text { is the (annual) financial weight of foreign (F) country } \\
n \text { in quarter } t ; i_{n, t}^{F} \text { is the foreign money market rate of country } n \text { in } \\
\text { quarter } t . \mathrm{n} \text { is the major currencies/currency areas: USD, GBP, } \\
\text { EUR, YEN, CHF. Financial weights based on foreign debt liabilities, } \\
\text { from Bénétrix et al. (2015), and extrapolated for } 2013 / 2014 \text { based } \\
\text { on } 2012 \text { values. We use discount rates or policy rates when } \\
\text { available for a longer time series than money market rates. }\end{array}$ & $\begin{array}{l}\text { IFS; Bénétrix } \\
\text { et al. (2015) }\end{array}$ \\
\hline $\begin{array}{l}\text { Number of } \\
\text { Borrowers }\end{array}$ & $\begin{array}{l}\text { Borrowers from commercial banks (per 1,ooo adults) is the } \\
\text { reported number of resident customers that are nonfinancial } \\
\text { corporations (public and private) and households who obtained }\end{array}$ & $\begin{array}{l}\text { World } \\
\text { Development } \\
\text { Indicators }\end{array}$ \\
\hline
\end{tabular}




\begin{tabular}{|c|c|c|}
\hline & $\begin{array}{l}\text { loans from commercial banks and other banks functioning as } \\
\text { commercial banks. For many countries data cover the total number } \\
\text { of loan accounts due to lack of information on loan account holders. }\end{array}$ & $\begin{array}{l}\text { Database, The } \\
\text { World Bank }\end{array}$ \\
\hline $\begin{array}{l}\text { Real GDP Growth } \\
\text { (Domestic) }\end{array}$ & $\begin{array}{l}\text { Quarterly GDP growth (yoy, \%). We use annual GDP growth (\% and } \\
\text { lagged by } 1 \text { year in the analysis rather than } 1 \text { quarter) where } \\
\text { quarterly GDP growth was not available for the full time series. }\end{array}$ & WEO, IMF \\
\hline $\begin{array}{l}\text { Real Houseprice } \\
\text { Growth }\end{array}$ & $\begin{array}{l}\text { Quarterly growth (\%) in real house prices based on the selected } \\
\text { property price series from the BIS. If these data are not available we } \\
\text { rely on data from Cesa-Bianchi et al. (2015). }\end{array}$ & $\begin{array}{l}\text { BIS and Cesa- } \\
\text { Bianchi et al. } \\
\text { (2015). }\end{array}$ \\
\hline $\begin{array}{l}\text { Risk-Adj. } \\
\text { Lending Rate }\end{array}$ & $\begin{array}{l}\text { Risk premium on lending (lending rate minus risk free treasury bill } \\
\text { rate, \%). Risk premium on lending is the interest rate charged by } \\
\text { banks on loans to private sector customers minus the "risk free" } \\
\text { treasury bill interest rate at which short-term government securities } \\
\text { are issued or traded in the market. }\end{array}$ & $\begin{array}{l}\text { World } \\
\text { Development } \\
\text { Indicators } \\
\text { Database, The } \\
\text { World Bank }\end{array}$ \\
\hline Rule of Law & $\begin{array}{l}\text { This variable is a proxy for the domestic risk premium factors that } \\
\text { affect stock market returns and is defined as: "perceptions of the } \\
\text { extent to which agents have confidence in and abide by the rules of } \\
\text { society, and in particular the quality of contract enforcement, } \\
\text { property rights, the police, and the courts, as well as the likelihood } \\
\text { of crime and violence." The original variable is of annual frequency } \\
\text { and has been interpolated to quarterly frequency. }\end{array}$ & $\begin{array}{l}\text { Worldwide } \\
\text { Governance } \\
\text { Indicators } \\
\text { Database, The } \\
\text { World Bank }\end{array}$ \\
\hline $\begin{array}{l}\text { Share of NP } \\
\text { Loans (\%) }\end{array}$ & $\begin{array}{l}\text { The value of nonperforming bank loans divided by the total value of } \\
\text { the loan portfolio (including nonperforming loans before the } \\
\text { deduction of specific loan-loss provisions). The loan amount } \\
\text { recorded as nonperforming should be the gross value of the loan as } \\
\text { recorded on the balance sheet, not just the amount that is overdue. }\end{array}$ & $\begin{array}{l}\text { World } \\
\text { Development } \\
\text { Indicators } \\
\text { Database, The } \\
\text { World Bank }\end{array}$ \\
\hline $\begin{array}{l}\text { Short-term } \\
\text { interest rate }\end{array}$ & $\begin{array}{l}\text { Quarterly change in the nominal money market rate. We use } \\
\text { discount rates or policy rates when those are available for a longer } \\
\text { time series than money market rates. }\end{array}$ & IFS \\
\hline Sovereign Ratings & $\begin{array}{l}\text { Quarterly sovereign foreign currency ratings from Fitch, S\&P and } \\
\text { Moody's are converted into a numerical scale ranging from o to } 20 \\
\text { before averaging across the three ratings. }\end{array}$ & $\begin{array}{l}\text { tradingecono } \\
\text { mics.com }\end{array}$ \\
\hline $\begin{array}{l}\text { Stock Market } \\
\text { Turnover Ratio } \\
\text { (\%) }\end{array}$ & $\begin{array}{l}\text { This variable is a proxy for domestic liquidity factors that affect } \\
\text { stock market returns and is defined as: "Total value of shares } \\
\text { traded during the period divided by the average market } \\
\text { capitalization for the period." The original variable is of annual } \\
\text { frequency and has been interpolated to quarterly frequency. }\end{array}$ & $\begin{array}{l}\text { Global } \\
\text { Financial } \\
\text { Development } \\
\text { Database, The } \\
\text { World Bank }\end{array}$ \\
\hline $\begin{array}{l}\text { Stock Returns - } \\
\text { Broad }\end{array}$ & $\begin{array}{l}\text { Quarter-on-quarter growth rates of the most commonly used stock } \\
\text { market index in each country. Growth rates computed as changes in } \\
\text { the natural logarithm. Index values are quarterly averages. }\end{array}$ & $\begin{array}{l}\text { Haver } \\
\text { Analytics }\end{array}$ \\
\hline $\begin{array}{l}\text { Stock Returns - } \\
\text { Financial }\end{array}$ & $\begin{array}{l}\text { Quarter-on-quarter growth rates of stock market indices that } \\
\text { comprise each country's major companies in the financial sector, } \\
\text { largely banks. Growth rates computed as changes in the natural } \\
\text { logarithm. Index values represent quarterly averages. }\end{array}$ & $\begin{array}{l}\text { Haver } \\
\text { Analytics }\end{array}$ \\
\hline
\end{tabular}




\section{Appendix Table A2: Summary Statistics for Baseline Regressions}

\begin{tabular}{|c|c|c|c|c|c|c|}
\hline Variable & Mean & Median & std. dev. & $\min$ & $\max$ & Obs. \\
\hline \multicolumn{7}{|l|}{ Dependent variables } \\
\hline \multicolumn{7}{|l|}{ Cross-bank loans to banks (\% of GDP) } \\
\hline All currencies & 0.235 & 0.067 & 2.203 & -6.993 & 10.028 & 3,593 \\
\hline$F X$ & 0.172 & 0.042 & 1.792 & -5.617 & 7.915 & 3,589 \\
\hline Non-FX & 0.055 & 0.011 & 0.765 & -3.14 & 4.053 & 3,535 \\
\hline Changes in Share & -0.092 & -0.09 & 3.524 & -9.372 & 9.335 & 3,531 \\
\hline \multicolumn{7}{|l|}{ Int. Debt Issuance by Corporates (\% of GDP) } \\
\hline All currencies & 0.069 & 0 & 0.223 & -0.339 & 0.939 & 3,420 \\
\hline$F X$ & 0.056 & 0 & 0.199 & -0.283 & 0.787 & 3,344 \\
\hline Non-FX & 0.014 & 0 & 0.07 & -0.163 & 0.49 & 2,736 \\
\hline Changes in Share & -0.073 & 0 & 1.332 & -6.364 & 4.784 & 2,804 \\
\hline \multicolumn{7}{|l|}{ FX regulations } \\
\hline \multicolumn{7}{|l|}{ FX regulations } \\
\hline All & 0.016 & 0 & 0.184 & -1 & 1 & 3,648 \\
\hline Asset-Side & 0.008 & 0 & 0.141 & -1 & 1 & 3,648 \\
\hline Liability-side & 0.009 & 0 & 0.127 & -1 & 1 & 3,648 \\
\hline Non-FX regulations & 0.032 & 0 & 0.407 & -1 & 1 & 3,648 \\
\hline \multicolumn{7}{|l|}{ Control variables } \\
\hline Global Volatility & 2.52 & 2.52 & 0.424 & 1.654 & 3.969 & 3,648 \\
\hline Global Growth & 3.487 & 3.46 & 1.617 & -1.88 & 7.29 & 3,648 \\
\hline Fed funds rate/Shadow rate (Changes) & -0.117 & -0.07 & 0.485 & -1.727 & 1 & 3,648 \\
\hline Real GDP Growth & 3.732 & 4.039 & 3.636 & -5.901 & 10.651 & 3,624 \\
\hline Volatility of exchange rate (FW) & 0.668 & 0.529 & 0.522 & 0.042 & 2.402 & 3,489 \\
\hline IR differential (Changes, FW) & -0.113 & -0.008 & 1.448 & -5.291 & 4.171 & 3,501 \\
\hline Sovereign Ratings & 13.008 & 13 & 4.578 & 0.333 & 20 & 3,527 \\
\hline Financial Openness (Changes) & 0.006 & 0 & 0.089 & -0.593 & 0.593 & 3,540 \\
\hline
\end{tabular}

Note: Quarterly capital inflows are scaled by annual GDP which is calculated as a 4-quarter moving average of annual data to avoid breaks due to annual GDP rising or falling from Q4 to Q1. We scale by annual GDP rather than quarterly GDP because the sum of the contemporaneous coefficient and three lags on $f x m_{i, t}$ in equation (16) can then be read as the effect on capital flows to annual GDP over one year. 


\section{Appendix B: Sensitivity Tests and Extensions}

This section includes a selection of the sensitivity tests reported and discussed in Sections IV and V.

\begin{tabular}{|c|c|c|c|c|c|c|c|c|c|}
\hline & \multicolumn{3}{|c|}{ IBS: Cross-border (XB) loans to non-banks } & \multicolumn{3}{|c|}{ IBS: Domestic bank loans to non-banks } & \multicolumn{3}{|c|}{ IDS: International debt issuance by banks } \\
\hline & $\begin{array}{c}\text { (1) } \\
\text { FX Inflows }\end{array}$ & $\begin{array}{c}\text { (2) } \\
\text { FX Share }\end{array}$ & $\begin{array}{c}\text { (3) } \\
\text { Non-FX } \\
\text { Inflows }\end{array}$ & $\begin{array}{c}\text { (4) } \\
\text { FX Inflows }\end{array}$ & $\begin{array}{c}\text { (5) } \\
\text { FX Share }\end{array}$ & $\begin{array}{c}\text { (6) } \\
\text { Non-FX } \\
\text { Inflows }\end{array}$ & $\begin{array}{c}\text { (7) } \\
\text { FX Inflows }\end{array}$ & $\begin{array}{c}\text { (8) } \\
\text { FX Share }\end{array}$ & $\begin{array}{c}\text { (9) } \\
\text { Non-FX } \\
\text { Inflows }\end{array}$ \\
\hline FX regulation ( $t$ to $t-3$ ) & $\begin{array}{l}0.0748 \\
0.721\end{array}$ & $\begin{array}{l}-0.209 \\
0.370\end{array}$ & $\begin{array}{c}0.00422 \\
0.914\end{array}$ & $\begin{array}{c}-0.956 * * \\
0.0466\end{array}$ & $\begin{array}{l}-1.485 \\
0.343\end{array}$ & $\begin{array}{l}-0.403 \\
0.358\end{array}$ & $\begin{array}{l}-0.110 * \\
0.0865\end{array}$ & $\begin{array}{l}-0.255 \\
0.118\end{array}$ & $\begin{array}{c}-0.00833 \\
0.885\end{array}$ \\
\hline Domestic variables & & & & & & & & & \\
\hline $\begin{array}{l}\text { Non-FX regulation ( } \mathrm{t} \text { to } \mathrm{t}-3 \text { ) } \\
\qquad p \text {-value }\end{array}$ & $\begin{array}{l}0.0778 \\
0.105\end{array}$ & $\begin{array}{l}-0.106 \\
0.500\end{array}$ & $\begin{array}{l}0.0140 \\
0.567\end{array}$ & $\begin{array}{l}0.140 \\
0.459\end{array}$ & $\begin{array}{l}-0.247 \\
0.771\end{array}$ & $\begin{array}{l}0.0614 \\
0.801\end{array}$ & $\begin{array}{c}0.0301 \\
0.317\end{array}$ & $\begin{array}{c}0.0782 \\
0.395\end{array}$ & $\begin{array}{c}0.0327 \\
0.275\end{array}$ \\
\hline Real GDP Growth (t-1) & $\begin{array}{c}0.0141^{* * *} \\
(0.0032)\end{array}$ & $\begin{array}{l}-0.0176 \\
(0.0120)\end{array}$ & $\begin{array}{l}0.0051 * * \\
(0.0021)\end{array}$ & $\begin{array}{l}-0.1758 * * \\
(0.0716)\end{array}$ & $\begin{array}{c}0.1447 \\
(0.1807)\end{array}$ & $\begin{array}{c}-0.1079 * \\
(0.0646)\end{array}$ & $\begin{array}{c}0.0011 \\
(0.0031)\end{array}$ & $\begin{array}{c}0.0160 * * \\
(0.0070)\end{array}$ & $\begin{array}{l}-0.0015 \\
(0.0024)\end{array}$ \\
\hline Volatility of exchange rate (FW, t-1) & $\begin{array}{l}-0.0110 \\
(0.0305)\end{array}$ & $\begin{array}{c}0.2827^{* *} \\
(0.1238)\end{array}$ & $\begin{array}{c}-0.0114 \\
(0.0125)\end{array}$ & $\begin{array}{l}-0.2216 \\
(0.2082)\end{array}$ & $\begin{array}{c}0.0480 \\
(0.8755)\end{array}$ & $\begin{array}{c}-0.4128 \\
(0.2551)\end{array}$ & $\begin{array}{c}0.0092 \\
(0.0182)\end{array}$ & $\begin{array}{c}0.0101 \\
(0.0526)\end{array}$ & $\begin{array}{c}0.0505 \\
(0.0353)\end{array}$ \\
\hline IR differential (Changes, FW, t-1) & $\begin{array}{c}-0.0032 \\
(0.0057)\end{array}$ & $\begin{array}{c}0.0037 \\
(0.0219)\end{array}$ & $\begin{array}{c}0.0010 \\
(0.0023)\end{array}$ & $\begin{array}{c}0.1614 \\
(0.1229)\end{array}$ & $\begin{array}{c}-0.1094 \\
(0.4593)\end{array}$ & $\begin{array}{c}0.0478 \\
(0.1238)\end{array}$ & $\begin{array}{c}0.0089 \\
(0.0062)\end{array}$ & $\begin{array}{c}0.0144 \\
(0.0126)\end{array}$ & $\begin{array}{l}-0.0030 \\
(0.0034)\end{array}$ \\
\hline Sovereign Ratings (t-1) & $\begin{array}{c}0.0525^{* * *} \\
(0.0126)\end{array}$ & $\begin{array}{c}-0.0620 * * \\
(0.0260)\end{array}$ & $\begin{array}{c}0.0119 * * * \\
(0.0042)\end{array}$ & $\begin{array}{c}0.4039 * * * \\
(0.1442)\end{array}$ & $\begin{array}{c}0.2545 \\
(0.2889)\end{array}$ & $\begin{array}{c}0.2842^{* * *} \\
(0.1011)\end{array}$ & $\begin{array}{l}0.0462 * \\
(0.0263)\end{array}$ & $\begin{array}{c}0.0170 \\
(0.0180)\end{array}$ & $\begin{array}{c}0.0175^{* * *} \\
(0.0062)\end{array}$ \\
\hline Financial Openness (Changes, t-4) & $\begin{array}{c}0.2450 \\
(0.2159)\end{array}$ & $\begin{array}{c}0.3266 \\
(0.3640)\end{array}$ & $\begin{array}{c}0.0334 \\
(0.0593)\end{array}$ & $\begin{array}{l}-0.4675 \\
(1.5806)\end{array}$ & $\begin{array}{c}2.5171 \\
(3.3464)\end{array}$ & $\begin{array}{c}0.2044 \\
(1.2114)\end{array}$ & $\begin{array}{c}0.0230 \\
(0.0685)\end{array}$ & $\begin{array}{c}-0.2968 \\
(0.2011)\end{array}$ & $\begin{array}{c}0.1969 \\
(0.1655)\end{array}$ \\
\hline Constant & $\begin{array}{c}-0.7301^{* * *} \\
(0.1950)\end{array}$ & $\begin{array}{c}0.3282 \\
(0.5485)\end{array}$ & $\begin{array}{c}-0.1514 * * \\
(0.0716)\end{array}$ & $\begin{array}{c}-5.7676 * * \\
(2.3006)\end{array}$ & $\begin{array}{l}-3.7932 \\
(4.3720)\end{array}$ & $\begin{array}{c}-4.1395^{* * *} \\
(1.5600)\end{array}$ & $\begin{array}{l}-0.5540 \\
(0.3457)\end{array}$ & $\begin{array}{l}-0.1252 \\
(0.3079)\end{array}$ & $\begin{array}{c}-0.2871 * * \\
(0.1271)\end{array}$ \\
\hline Time Fixed Effects & Yes & Yes & Yes & Yes & Yes & Yes & Yes & Yes & Yes \\
\hline Observations & 3,381 & 3,345 & 3,360 & 138 & 138 & 138 & 3,321 & 2,619 & 2,054 \\
\hline Adj. R-squared & 0.118 & 0.042 & 0.061 & 0.267 & 0.137 & 0.198 & 0.210 & 0.016 & 0.109 \\
\hline Countries & 48 & 48 & 48 & 15 & 15 & 15 & 47 & 45 & 28 \\
\hline
\end{tabular}

Appendix Table B1: Impact of FX macroprudential regulations on cross-border and domestic loans to non-banks, and international debt issuance by banks

Variables and definitions are the same as in Tables 1 and 2. 


\begin{tabular}{|c|c|c|c|c|c|c|c|c|c|c|c|c|}
\hline & \multicolumn{6}{|c|}{ Exclude offshore centres } & \multicolumn{6}{|c|}{ Exclude global financial crisis } \\
\hline & \multicolumn{3}{|c|}{ IBS: Cross-border loans to banks } & \multicolumn{3}{|c|}{ IDS: Int. debt issuance by corporates } & \multicolumn{3}{|c|}{ IIBS: Cross-border loans to banks } & \multicolumn{3}{|c|}{ IDS: Int. debt issuance by corporates } \\
\hline & (1) & (2) & (3) & (4) & (5) & (6) & (7) & $(8)$ & (9) & (10) & $(11)$ & $(12)$ \\
\hline & FXInflows & FX Share & $\begin{array}{l}\text { Non-FX } \\
\text { Inflows }\end{array}$ & FX Inflows & FX Share & $\begin{array}{l}\text { Non-FX } \\
\text { Inflows }\end{array}$ & FX Inflows & FX Share & $\begin{array}{l}\text { Non-FX } \\
\text { Inflows }\end{array}$ & FX Inflows & FX Share & $\begin{array}{l}\text { Non-FX } \\
\text { Inflows }\end{array}$ \\
\hline FX regulation ( $t$ to $t-3$ ) & $-0.524 * *$ & $-0.997 * *$ & 0.0744 & $0.0531 * *$ & $0.506 * *$ & 0.00922 & $-0.548 * *$ & $-1.030 * * *$ & 0.111 & $0.0526 * *$ & $0.537^{* *}$ & 0.00229 \\
\hline$p$-value & 0.0361 & 0.0114 & 0.522 & 0.0432 & 0.0271 & 0.785 & 0.0343 & 0.00656 & 0.381 & 0.0420 & 0.0315 & 0.943 \\
\hline \multicolumn{13}{|l|}{ Domestic variables } \\
\hline Non- $F X$ regulation ( $t$ to $t-3$ ) & 0.0830 & -0.122 & 0.113 & -0.000343 & 0.0750 & -0.00407 & 0.230 & -0.147 & 0.163 & -0.00153 & 0.0749 & -0.00285 \\
\hline$p$-value & 0.477 & 0.554 & 0.224 & 0.986 & 0.446 & 0.409 & 0.173 & 0.471 & 0.116 & 0.938 & 0.466 & 0.606 \\
\hline Real GDP Growth (t-1) & $\begin{array}{c}0.0451^{* * *} \\
(0.0098)\end{array}$ & $\begin{array}{c}0.0198 \\
(0.0154)\end{array}$ & $\begin{array}{l}0.0159^{*} \\
(0.0080)\end{array}$ & $\begin{array}{c}0.0026^{* *} \\
(0.0012)\end{array}$ & $\begin{array}{c}-0.0028 \\
(0.0084)\end{array}$ & $\begin{array}{c}-0.0002 \\
(0.0004)\end{array}$ & $\begin{array}{c}0.0652^{* * *} \\
(0.0171)\end{array}$ & $\begin{array}{l}0.0274^{*} \\
(0.0157)\end{array}$ & $\begin{array}{c}0.0156^{* *} \\
(0.0077)\end{array}$ & $\begin{array}{c}0.0020 \\
(0.0014)\end{array}$ & $\begin{array}{c}0.0043 \\
(0.0078)\end{array}$ & $\begin{array}{l}-0.0002 \\
(0.0004)\end{array}$ \\
\hline Volatility of exchange rate (FW, t-1) & $\begin{array}{l}-0.1252 \\
(0.1002)\end{array}$ & $\begin{array}{c}0.0886 \\
(0.1705)\end{array}$ & $\begin{array}{c}0.0690 * * \\
(0.0315)\end{array}$ & $\begin{array}{c}0.0119 \\
(0.0109)\end{array}$ & $\begin{array}{c}0.0262 \\
(0.0436)\end{array}$ & $\begin{array}{l}-0.0069 * \\
(0.0040)\end{array}$ & $\begin{array}{l}-0.1559 \\
(0.1437)\end{array}$ & $\begin{array}{c}0.1774 \\
(0.1778)\end{array}$ & $\begin{array}{c}0.0502 \\
(0.0319)\end{array}$ & $\begin{array}{c}0.0130 \\
(0.0115)\end{array}$ & $\begin{array}{c}0.0479 \\
(0.0465)\end{array}$ & $\begin{array}{c}-0.0075^{*} \\
(0.0041)\end{array}$ \\
\hline IR differential (Changes, FW, t-1) & $\begin{array}{c}0.0169 \\
(0.0136)\end{array}$ & $\begin{array}{c}0.0118 \\
(0.0622)\end{array}$ & $\begin{array}{l}-0.0104 \\
(0.0067)\end{array}$ & $\begin{array}{c}-0.0036^{* *} \\
(0.0016)\end{array}$ & $\begin{array}{l}-0.0135 \\
(0.0166)\end{array}$ & $\begin{array}{c}0.0003 \\
(0.0005)\end{array}$ & $\begin{array}{c}0.0021 \\
(0.0180)\end{array}$ & $\begin{array}{l}-0.0087 \\
(0.0631)\end{array}$ & $\begin{array}{l}-0.0055 \\
(0.0063)\end{array}$ & $\begin{array}{l}-0.0031 \\
(0.0019)\end{array}$ & $\begin{array}{l}-0.0137 \\
(0.0164)\end{array}$ & $\begin{array}{c}0.0004 \\
(0.0004)\end{array}$ \\
\hline Sovereign Ratings (t-1) & $\begin{array}{c}0.0795^{* * *} \\
(0.0226)\end{array}$ & $\begin{array}{c}-0.0628^{*} \\
(0.0363)\end{array}$ & $\begin{array}{c}0.0499 * * * \\
(0.0175)\end{array}$ & $\begin{array}{c}0.0095 \\
(0.0066)\end{array}$ & $\begin{array}{c}0.0037 \\
(0.0147)\end{array}$ & $\begin{array}{l}-0.0008 \\
(0.0014)\end{array}$ & $\begin{array}{c}0.0728 * * \\
(0.0275)\end{array}$ & $\begin{array}{l}-0.0547 \\
(0.0362)\end{array}$ & $\begin{array}{c}0.0456 * * * \\
(0.0157)\end{array}$ & $\begin{array}{c}0.0108 \\
(0.0066)\end{array}$ & $\begin{array}{c}0.0026 \\
(0.0147)\end{array}$ & $\begin{array}{l}-0.0012 \\
(0.0015)\end{array}$ \\
\hline Financial Openness (Changes, t- 4 ) & $\begin{array}{c}0.3505 \\
(0.2684)\end{array}$ & $\begin{array}{c}0.4595 \\
(0.8139)\end{array}$ & $\begin{array}{l}-0.0183 \\
(0.1610)\end{array}$ & $\begin{array}{c}0.0163 \\
(0.0497)\end{array}$ & $\begin{array}{c}0.3368 \\
(0.2269)\end{array}$ & $\begin{array}{c}-0.0193^{*} \\
(0.0114)\end{array}$ & $\begin{array}{c}0.2548 \\
(0.2290)\end{array}$ & $\begin{array}{c}0.4532 \\
(0.8369)\end{array}$ & $\begin{array}{l}-0.0105 \\
(0.1599)\end{array}$ & $\begin{array}{c}0.0126 \\
(0.0475)\end{array}$ & $\begin{array}{c}0.3481 \\
(0.2427)\end{array}$ & $\begin{array}{c}-0.0194 \\
(0.0135)\end{array}$ \\
\hline Constant & $\begin{array}{c}-0.9833^{* *} \\
(0.3742)\end{array}$ & $\begin{array}{c}1.0596 \\
(0.8187)\end{array}$ & $\begin{array}{c}-0.6639 * * \\
(0.2622)\end{array}$ & $\begin{array}{l}-0.1102 \\
(0.0930)\end{array}$ & $\begin{array}{c}0.0328 \\
(0.2755)\end{array}$ & $\begin{array}{c}0.0152 \\
(0.0168)\end{array}$ & $\begin{array}{c}-1.1222^{* *} \\
(0.4458)\end{array}$ & $\begin{array}{c}0.8854 \\
(0.7905)\end{array}$ & $\begin{array}{c}-0.6060^{* *} \\
(0.2413)\end{array}$ & $\begin{array}{l}-0.1294 \\
(0.0938)\end{array}$ & $\begin{array}{c}0.0514 \\
(0.2689)\end{array}$ & $\begin{array}{c}0.0198 \\
(0.0182)\end{array}$ \\
\hline Time Fixed Effects & Yes & Yes & Yes & Yes & Yes & Yes & Yes & Yes & Yes & Yes & Yes & Yes \\
\hline Observations & 3,229 & 3,196 & 3,216 & 2,995 & 2,576 & 2,461 & 3,189 & 3,161 & 3,176 & 2,971 & 2,568 & 2,469 \\
\hline Adj. R-squared & 0.09 & 0.011 & 0.049 & 0.102 & 0.038 & 0.212 & 0.091 & 0.014 & 0.058 & 0.097 & 0.042 & 0.198 \\
\hline Countries & 46 & 45 & 46 & 42 & 42 & 34 & 48 & 47 & 48 & 44 & 44 & 36 \\
\hline
\end{tabular}

\section{Appendix Table B2: Sensitivity analysis of the impact of macroprudential FX regulations}

All variable definitions and notes are the same as for Table 1. In columns (1) to (6), we exclude offshore financial centers as classified by the BIS (i.e., Hong Kong and Singapore). In columns (7) to (12), we exclude the quarters from 2008 Q3 to 2009 Q2, i.e., the quarters from the collapse of Lehman brothers until banking flows stabilized. 


\begin{tabular}{|c|c|c|c|c|c|c|}
\hline \multirow[b]{2}{*}{ Stock Returns } & \multicolumn{2}{|c|}{ Lag Key Variables } & \multicolumn{2}{|c|}{ Exclude Annual Vars } & \multicolumn{2}{|c|}{ Exclude 2008Q4 } \\
\hline & $(1)$ & $(2)$ & (3) & (4) & (5) & (6) \\
\hline By & Fin. & Broad & Fin. & Broad & Fin. & Broad \\
\hline \multirow[t]{2}{*}{ Cum. FX Regulation ( $t$ to $t-3$ ) } & -1.707 & -0.989 & -1.230 & -0.465 & -1.404 & -0.541 \\
\hline & $(1.358)$ & $(1.273)$ & $(1.305)$ & $(1.401)$ & $(1.334)$ & $(1.478)$ \\
\hline \multirow[t]{2}{*}{ Ex. Rate Appreciation (FW) (t) } & $1.880 * * *$ & $1.605^{* * *}$ & $1.472^{* * *}$ & $1.221 * * *$ & $1.415^{* * *}$ & $1.117^{* * *}$ \\
\hline & $(0.217)$ & $(0.156)$ & $(0.214)$ & $(0.156)$ & $(0.231)$ & $(0.169)$ \\
\hline \multirow[t]{2}{*}{ FX Regulation X Ex. Rate Apprec. (FW) (t) } & $-0.700 * *$ & -0.402 & $-0.741 * *$ & $-0.445^{*}$ & $-0.894 * * *$ & $-0.467^{*}$ \\
\hline & $(0.334)$ & $(0.250)$ & $(0.269)$ & $(0.221)$ & $(0.293)$ & $(0.241)$ \\
\hline \multirow[t]{2}{*}{ Industry Production Growth (t) } & -0.013 & 0.014 & $0.087^{*}$ & 0.060 & $0.086^{*}$ & 0.058 \\
\hline & $(0.046)$ & (0.039) & $(0.043)$ & $(0.044)$ & $(0.043)$ & $(0.040)$ \\
\hline \multirow[t]{2}{*}{ Inflation $(t)$} & $-1.825 * * *$ & $-2.115^{* * *}$ & -0.159 & -0.161 & -0.249 & -0.456 \\
\hline & $(0.342)$ & $(0.292)$ & $(0.413)$ & $(0.318)$ & $(0.420)$ & $(0.308)$ \\
\hline \multirow[t]{2}{*}{ Short-Term Interest Rate (t) } & -0.192 & -0.318 & $-0.223^{*}$ & $-0.388 * *$ & $-0.279 *$ & $-0.408 * *$ \\
\hline & $(0.184)$ & $(0.221)$ & $(0.112)$ & $(0.160)$ & $(0.149)$ & $(0.193)$ \\
\hline \multirow[t]{2}{*}{ Stock Market Turnover Ratio (t) } & -0.037 & -0.007 & & & 0.018 & $0.050 * * *$ \\
\hline & $(0.022)$ & $(0.020)$ & & & $(0.020)$ & $(0.016)$ \\
\hline \multirow[t]{2}{*}{ Rule of Law (t) } & 0.239 & 3.476 & & & -3.874 & -1.189 \\
\hline & (3.296) & (3.820) & & & (3.161) & $(3.631)$ \\
\hline \multirow[t]{2}{*}{ Global Volatility (t) } & $-3.620 * * *$ & $-2.515^{* * *}$ & $-9.833 * * *$ & $-9.288 * * *$ & $-9.278 * * *$ & $-8.923 * * *$ \\
\hline & $(0.507)$ & $(0.498)$ & $(0.754)$ & $(0.669)$ & $(0.899)$ & $(0.772)$ \\
\hline Country Fixed Effects & Yes & Yes & Yes & Yes & Yes & Yes \\
\hline Observations & 1,095 & 1,095 & 1,125 & 1,125 & 1,073 & 1,073 \\
\hline R-squared & 0.23 & 0.25 & 0.34 & 0.38 & 0.26 & 0.30 \\
\hline Number of Countries & 23 & 23 & 23 & 23 & 23 & 23 \\
\hline
\end{tabular}

\section{Appendix Table B3: Sensitivity analysis of market vulnerability to currency movements}

The table shows the estimated parameter values from a panel regression of equation (17). All columns include country fixed effects. The dependent variables are stock returns of financials ("Fin."; which is primarily banks), the broad market ("Broad"; which includes both banks, non-bank financial institutions, and corporates) and an artificial series of corporate stock returns ("Corp."; corresponding to the residuals of a regression of broad market stock returns on financial stock returns). Columns (1) and (2) lag all the control variables (except the first three) by one quarter. Columns (3) and (4) exclude the Stock Market Turnover Ratio and the Rule of Law variables, which are interpolated from annual to quarterly frequency. Columns (5) and (6) exclude 2008Q4, which contains the largest exchange rate movement in the sample. The specifications and data are discussed in Section III. Additional information is provided in in Appendix A. The sample period is 2000 Q1 - 2014 Q4. Robust standard errors are clustered at the country level and reported in brackets. ${ }^{* *} /{ }^{* *} /{ }^{*}$ is significant at the $1 \%$, $5 \%$, and $10 \%$ levels, respectively. The larger value of each coefficient pair in absolute terms is marked in bold. 